\title{
Impact of dust on tropospheric chemistry over polluted regions: a case study of the Beijing megacity
}

\author{
S. Zhu ${ }^{1,2}$, T. Butler ${ }^{2}$, R. Sander ${ }^{2}$, J. Ma ${ }^{1}$, and M. G. Lawrence ${ }^{2,3}$ \\ ${ }^{1}$ Chinese Academy of Meteorological Sciences, Beijing, China \\ ${ }^{2}$ Max Planck Institute for Chemistry, Mainz, Germany \\ ${ }^{3}$ University of Mainz, Mainz, Germany
}

Received: 11 August 2009 - Published in Atmos. Chem. Phys. Discuss.: 25 September 2009

Revised: 15 April 2010 - Accepted: 15 April 2010 - Published: 26 April 2010

\begin{abstract}
The box model MECCA (Module Efficiently Calculating the Chemistry of the Atmosphere) is extended by incorporating detailed heterogeneous chemistry occurring on mineral aerosol surfaces. The model is used to investigate the impact of dust on tropospheric photochemistry, when the dust is transported to a polluted region, focusing on the example of Beijing. The impacts of dust via heterogeneous removal of gases are analyzed for different hypothetical transport rates, which are described by four different exchange rate coefficients $K_{t}$ in the model. Along with the dust, airmasses with trace gas levels characteristic for regions upwind of Beijing are transported with the same rate $\left(K_{t}\right)$. Substantial impacts are found for many gases, including $\mathrm{O}_{\mathrm{x}}\left(\mathrm{O}_{3}+\mathrm{O}\left({ }^{3} \mathrm{P}\right)\right), \mathrm{NO}_{\mathrm{x}}\left(\mathrm{NO}+\mathrm{NO}_{2}\right)$ and $\mathrm{OH}$. The $\mathrm{O}_{\mathrm{x}}$ daily average mixing ratio decreases due to heterogeneous reactions on dust. The change ranges from -2.5 to $-18.4 \mathrm{nmol} \mathrm{mol}^{-1}$, and is larger for faster mixing with upwind air masses (i.e. greater $K_{t}$ ). This translates into a large relative change in $\mathrm{O}_{\mathrm{x}}$, ranging from $-44 \%$ to $-55 \%$, depending on $K_{t}$. By assuming an artificial $50 \%$ decrease of all photolysis rates, the impacts of dust via perturbation of the photolysis rates in the polluted region are also estimated. Furthermore, the uncertainties in the results due to the uncertainties in the uptake coefficients are evaluated. It is found that for all gases which are heterogeneously removed, the self-removal results in the largest uncertainty (e.g. $-49 \%$ for $\mathrm{O}_{3},-76 \%$ for $\mathrm{NO}_{2},-47 \%$ for $\mathrm{HNO}_{3},-92 \%$ for $\mathrm{HCHO}$, $-64 \%$ for $\mathrm{CH}_{3} \mathrm{OH}$ and $-93 \%$ for $\mathrm{SO}_{2}$ ). The heterogeneous removal of $\mathrm{NO}_{2}$ is found to be particularly important, because it results in significant levels of uncertainty not only for
\end{abstract}

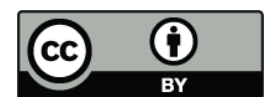

Correspondence to: M. G. Lawrence (lawrence@mpch-mainz.mpg.de) itself, but also for $\mathrm{OH}(340 \%)$ and $\mathrm{HO}_{2}(365 \%)$. Moreover, the heterogeneous removal rates of $\mathrm{HCHO}$ and $\mathrm{O}_{3}$ also have farther-reaching effects on the $\mathrm{OH}$ concentration (resulting in changes of $-55 \%$ and $45 \%$, respectively), and the heterogeneous removal of $\mathrm{HCHO}$ results in an uncertainty of $-38 \%$ in the $\mathrm{HO}_{2}$ concentration. The limitations of MECCA due to its missing oxidation mechanism for aromatics and other higher VOC species has also been considered, and shown to be potentially important in the quantitative results, though not likely to change the qualitative results of this study.

\section{Introduction}

The dust aerosol plays an important role in the physical, chemical, and ecological processes in the earth's system: it is suspected to play a large role in the earth's radiation budget (IPCC, 2007; Haywood et al., 2003; Highwood et al., 2003; Kaufman et al., 2002; Reddy et al., 2005; Stier et al., 2007); it influences ocean and terrestrial biogeochemistry by transporting nutrients like iron (Jickells et al., 2005); and it influences atmospheric chemistry by providing large surfaces for heterogeneous reactions and deposition and mixing with other smaller aerosols (e.g., Dentener et al., 1996.)

Chemical box models as well as global and regional chemistry-transport models have been used to calculate the changes in trace gas mixing ratios due to heterogeneous reactions on mineral dust aerosols. Zhang et al. (1994) and Zhang and Carmichael (1999), for example, used a box model to simulate the loss of $\mathrm{SO}_{2}, \mathrm{NO}_{\mathrm{x}}, \mathrm{HO}_{2}$ and $\mathrm{O}_{3}$ due to heterogeneous reactions on mineral dust aerosol. They found that the presence of dust resulted in decreases in the concentrations of $\mathrm{SO}_{2}(10 \%-53 \%), \mathrm{NO}_{\mathrm{y}}^{\mathrm{p}}(16 \%-100 \%$,

Published by Copernicus Publications on behalf of the European Geosciences Union. 


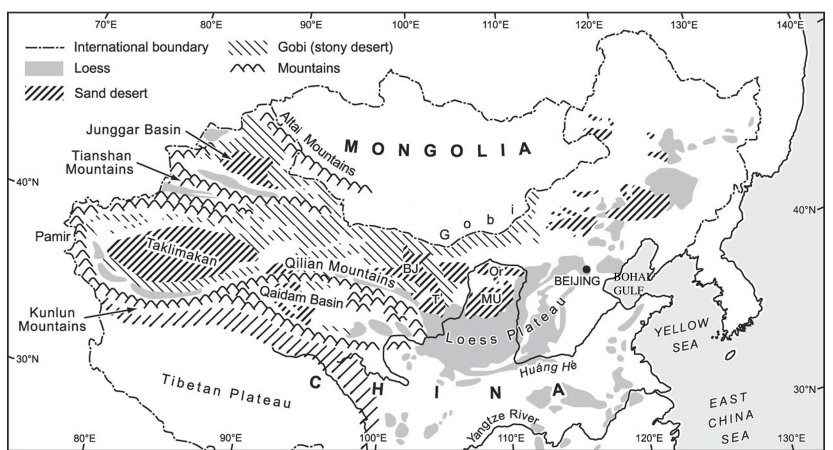

Fig. 1. The distribution map of Chinese Loess Plateau and surrounding primary desert dust source areas (Maher et al., 2009).

defined as $\left.\mathrm{NO}_{3}+\mathrm{N}_{2} \mathrm{O}_{5}+\mathrm{HNO}_{3}\right), \mathrm{H}_{\mathrm{x}} \mathrm{O}_{y}(11 \%-59 \%$, defined as $\left.\mathrm{OH}+\mathrm{HO}_{2}+\mathrm{H}_{2} \mathrm{O}_{2}\right)$, and $\mathrm{O}_{3}(11 \%-40 \%)$ under model conditions representative of spring dust storms in East Asia. Dentener et al. (1996) performed simulations with a global chemistry-transport model and calculated an $\mathrm{O}_{3}$ reduction up to $10 \%$ in and nearby dust source areas. De Reus et al. (2000) calculated a $30-40 \%$ reduction of $\mathrm{O}_{3}$ in a Saharan dust plume near the coast of Africa, attributed to the direct removal of $\mathrm{O}_{3}$ and $\mathrm{HNO}_{3}$. Bian and Zender (2003) found a very small effect (less than 1\%) on the global mean $\mathrm{O}_{3}$ burden while Bauer et al. (2004) predicted a decrease in the $\mathrm{O}_{3}$ burden of $5 \%$ due to heterogeneous reactions on mineral dust. Tie et al. (2005) calculated a maximum reduction of $\mathrm{HO}_{\mathrm{x}}$ and $\mathrm{O}_{3}$ concentrations of $30 \%$ and $20 \%$, respectively, over the Sahara desert. In general the effect on surface $\mathrm{O}_{3}$ concentrations is found to be globally small, but can be significant in dust aerosol source regions such as eastern Asia, the western United States and central Africa.

Mineral dust can affect the tropospheric ozone concentration directly by adsorption of ozone and indirectly by the heterogeneous reactions of ozone precursors (e.g., $\mathrm{NO}_{2}$ and $\mathrm{RO}_{2}$ ). The relationships between tropospheric ozone and its precursors are quite non-linear. Consequently, when dust encounters fresh pollutants, these heterogeneous reactions can lead to a series of complex responses of the photochemical system (Tang et al., 2004). Moreover, mineral dust aerosols can influence tropospheric ozone by changing the photolysis rates of $\mathrm{O}_{3}, \mathrm{NO}_{2}$, etc.

Although all studies indicate a strong regional influence of mineral dust aerosols on tropospheric chemistry, the results vary greatly. This is mainly due to the large uncertainty in the uptake coefficients for the different trace gases on mineral dust aerosols (e.g., De Reus et al. (2000) calculated that the $\mathrm{O}_{3}$ mixing ratio ranged from 29 to $45 \mathrm{nmol} \mathrm{mol}^{-1}$ using an accommodation coefficient of $10^{-4}$ and $10^{-5}$, respectively) and the representation of aerosols (e.g., bulk approach versus size resolved and internally mixed aerosols). Moreover, for box model calculations it is difficult to provide realistic initial and boundary conditions, while for 3-D models the resolution is a challenge, and for all models the comparison with observations is a major challenge.

In this paper we further explore the potential impact of mineral aerosol on tropospheric chemistry, under conditions characteristic of a polluted region. We focus on the example of Beijing city $\left(39.92^{\circ} \mathrm{N}, 116.46^{\circ} \mathrm{E}\right)$, the capital city of China. In addition to high anthropogenic emissions, Beijing is also frequently affected by dust storms in spring, which originate from dry regions like the Taklimakan Desert, the Gobi Desert and the Loess areas (Gong et al., 2006) (Fig. 1). For this study, the chemistry box model MECCA (Module Efficiently Calculating the Chemistry of the Atmosphere) is extended by combining dust surface uptake processes with detailed gas-phase chemistry. We assume that the upwind air masses including dust and gases are transported into the polluted region at various mean velocities. The influences of dust via heterogeneous removal of gases and perturbations of the photolysis rates are investigated. In particular, considering the above-mentioned complex responses of the photochemical system, we focus on determining the contributions of the various effects, using chemical budget equations together with the box model outputs, and on qualifying the uncertainty due to the lack of exact knowledge of uptake coefficients.

Section 2 describes the heterogeneous removal processes considered in this study and our modeling setup. In Sect. 3 the results of our model runs are discussed and the uncertainties in the uptake coefficients are analyzed. Section 4 provides a summary of the main results with conclusions.

\section{Model description}

To investigate the influence of dust aerosol on the mixing ratios of ozone and other reactive gases, model calculations are performed with the chemistry box model MECCA. The chemical reaction scheme has been described by Sander et al. (2005) and includes detailed chemistry of organic species with up to four C-atoms and isoprene (von Kuhlmann et al., 2003). The reaction rates have generally been adopted from the Jet Propulsion Laboratory (JPL) 2003 database (Sander et al., 2003) and the Master Chemical Mechanism (MCM) (http://mcm.leeds.ac.uk/MCM/).

For this study 12 heterogeneous removal reactions on mineral dust (listed in Table 1) have been added to the chemical scheme. In order to describe the transport of dust and gases over polluted regions, three physical processes have been incorporated, including: (1) inflow of upwind dust-rich air masses, (2) deposition and (3) emissions. Sensitivity simulations have been performed with four different exchange coefficients which are used to represent a range of transport velocities. These aspects of the model setup are described in detail in the following subsections. 
Table 1. Heterogeneous removal reactions and reactive uptake coefficients.

\begin{tabular}{lllll}
\hline No. & Heterogeneous reactions & "Best Guess" & Lower Limit & Upper Limit \\
\hline $\mathrm{HR} 1$ & $\mathrm{O}_{3} \rightarrow$ Dummy & $2.7 \times 10^{-5}$ & $1 \times 10^{-6}$ & $1 \times 10^{-4}$ \\
$\mathrm{HR} 2$ & $\mathrm{HNO}_{3} \rightarrow$ Dummy & 0.17 & $1 \times 10^{-5}$ & 0.2 \\
$\mathrm{HR} 3$ & $\mathrm{NO}_{2} \rightarrow$ Dummy & $2.1 \times 10^{-6}$ & $4 \times 10^{-10}$ & $2 \times 10^{-4}$ \\
$\mathrm{HR} 4$ & $\mathrm{NO}_{3} \rightarrow$ Dummy & 0.1 & 0.01 & 0.23 \\
$\mathrm{HR} 5$ & $\mathrm{~N}_{2} \mathrm{O}_{5} \rightarrow$ Dummy & 0.03 & 0.01 & 0.1 \\
$\mathrm{HR} 6$ & $\mathrm{OH} \rightarrow$ Dummy & 0.1 & 0.004 & 1 \\
$\mathrm{HR} 7$ & $\mathrm{HO}_{2} \rightarrow \mathrm{H}_{2} \mathrm{O}_{2}$ & 0.2 & 0.01 & 1 \\
$\mathrm{HR} 8$ & $\mathrm{H}_{2} \mathrm{O}_{2} \rightarrow$ Dummy & $2 \times 10^{-3}$ & $8 \times 10^{-4}$ & 0.18 \\
$\mathrm{HR} 9$ & $\mathrm{SO}_{2} \rightarrow$ Dummy & $3 \times 10^{-5}$ & $5 \times 10^{-7}$ & $2.6 \times 10^{-4}$ \\
$\mathrm{HR} 10$ & $\mathrm{CH}_{3} \mathrm{COOH} \rightarrow$ Dummy & $1 \times 10^{-3}$ & $2.4 \times 10^{-4}$ & $2 \times 10^{-3}$ \\
$\mathrm{HR} 11$ & $\mathrm{CH}_{3} \mathrm{OH} \rightarrow$ Dummy & $1 \times 10^{-5}$ & $4 \times 10^{-6}$ & $1.9 \times 10^{-4}$ \\
$\mathrm{HR} 12$ & $\mathrm{HCHO} \rightarrow$ Dummy $\mathrm{H} \rightarrow 1 \times 10^{-5}$ & $2.6 \times 10^{-7}$ & $1.1 \times 10^{-4}$ \\
\hline
\end{tabular}

\subsection{Heterogeneous removal reactions}

Heterogeneous reactions can deplete gas-phase species by condensation or deposition on aerosol particles. The removal rate of gas-phase species $i$ by aerosol particles can be described by a pseudo first-order rate coefficient $\left(\mathrm{s}^{-1}\right)$, given by Heikes and Thompson (1983):

$k_{i}=\int_{r_{\min }}^{r_{\max }} k_{m t, i}(r) n(r) d r$,

where $n(r) d r\left(\mathrm{~cm}^{-3}\right)$ represents the number concentration of particles with a radius between $r$ and $r+d r$ and $k_{m t, i}(r)$ is the size-dependent mass transfer coefficient $\left(\mathrm{m}^{3} \mathrm{~s}^{-1}\right)$, which can be calculated using the formulation given by Fuchs and Sutugin (1970):

$k_{m t, i}=\frac{4 \pi D_{i} V}{1+K_{n}[\chi+4(1-\alpha) / 3 \alpha]}$,

where $D_{i}\left(\mathrm{~cm}^{2} \mathrm{~s}^{-1}\right)$ is the gas phase molecular diffusion coefficient of species $i, V$ is the ventilation coefficient, which is close to unity, and $K_{n}$ is the dimensionless Knudsen number, which is defined as the ratio of the effective mean free path of a gas molecule in air, $\lambda$, to the particle radius $r$, and $\chi$ represents a correction factor for anisotropic movement and is dependent on the Knudsen number. The parameter $\alpha$ is the mass accommodation coefficient (or sticking coefficient), which is a dimensionless number defined as the number of molecules adsorbed by the surface of an aerosol divided by the number of collisions with the aerosol. An alternate parameterization by Schwartz (1986) was used by Dentener et al. (1996), Zhang and Carmichael (1999), de Reus et al. (2000) and de Reus et al. (2005). We have tested using this instead, and find that all results differ by less than $5 \%$ compared to using Eq. (B4).
There are two important parameters for interactions of gases with dust surfaces: the mass accommodation coefficient, $\alpha$, and the reactive uptake coefficient, $\gamma, \gamma$ represents the fraction of collisions with a particle that leads to irreversible loss of the gas, whereas $\alpha$ only indicates the reversible adsorption. The value of $\alpha$ usually represents an upper limit of $\gamma$. For the calculation of the gas removal rate in the model, we use values of $\gamma$ based on laboratory studies.

In recent years, numerous measurements of the accommodation or uptake coefficient on mineral aerosol have been performed and have been used in model studies. A discussion of the available measurements for the species of interest and the values used in other model studies, along with those selected for use in our simulations are given in Appendix A. The 12 heterogeneous removal pathways, along with the "best guess" values and the lower and upper limits for the reactive uptake coefficient of the different gases on dust aerosol mentioned above are listed in Table 1.

\subsection{Inflow, deposition and emission}

In this work, three physical processes are included in the box model MECCA: (1) inflow of upwind dust-rich air masses, (2) deposition and (3) emissions, as described below.

We consider the transport of dust and gases in a highly simplified way, by replacing a fraction of the air mass in the box directly by the incoming air mass, so that the tendency is calculated as:

$\frac{\partial C_{i}}{\partial t}=\left(C_{i}^{\prime}-C_{i}\right) \cdot f$,

where $C_{i}^{\prime}$ is the concentration of component $i$ (dust and gases) in the upwind air masses, $t$ is the modeling time step and $f$ is the exchange rate coefficient, which is defined as the fraction of air mass in the box replaced per unit time by the incoming air mass (note that $f$ is the same for all components i). 


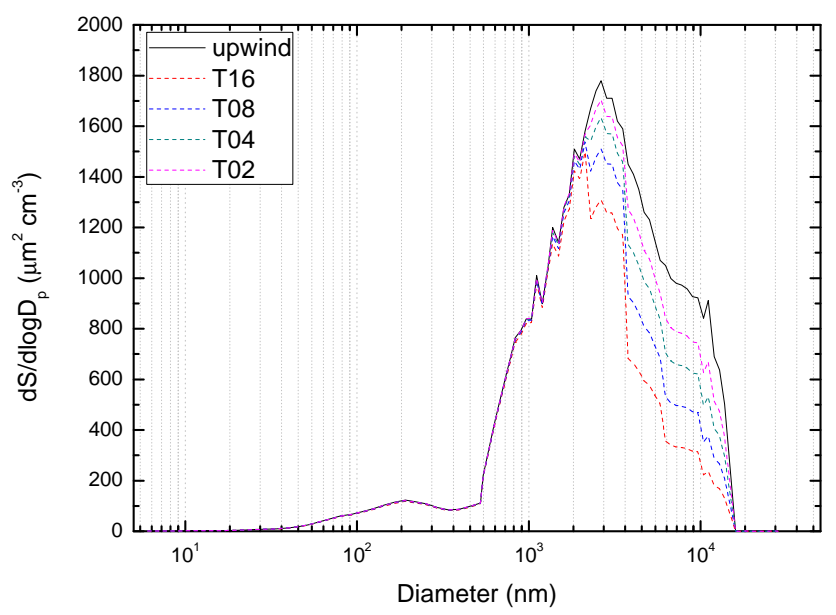

Fig. 2. Size distribution of dust surface area concentration in upwind air mass and in the box, for the four exchange rates used in the study.

We assume a homogeneous vertical distribution of all the simulated species in the boundary layer. For the emitted species, the increase in concentration $C_{i}$ (which we call the source term, $B_{e}$ ) can be calculated from the emission flux $J_{e}$ and the height of the boundary layer $Z_{p b l}$ :

$B_{e}=\frac{\partial C_{i}}{\partial t}=\frac{J_{e}}{Z_{p b l}}$.

The deposition flux $J_{d}$ for the dry deposition can be parameterized as the product of the concentration $C_{i}$ and the deposition velocity $v_{d}$ :

$J_{d}=-v_{d} C_{i}$.

To obtain the concentration change, the deposition flux is divided by the height of the boundary layer $Z_{p b l}$ :

$\frac{\partial C_{i}}{\partial t}=-\frac{v_{d} C_{i}}{Z_{p b l}}$.

where $v_{d} / \mathrm{Z}_{p b l}$ is defined as the deposition coefficient $K_{d}$. Note that the parameters $J_{e}$ (and thus $B_{e}$ ) and $v_{d}$ (and thus $K_{d}$ ) differ for each species $i$; these are discussed further in the following sections, and information on their values is given in Table 2. Wet deposition is not included in this study, considering that dust storm events only occur when it is not raining.

\subsection{Input parameters}

The air parcel encompasses the boundary layer, which is assumed to be uniformly mixed up to $756 \mathrm{~m}$. Temperature, air pressure, and relative humidity as input parameters are kept constant during the simulations at $284.35 \mathrm{~K}$, $943.17 \mathrm{hPa}$, and $44 \%$, respectively. These physical parameters, the initial gas-phase species concentrations $C_{i}$ and the upwind gas-phase species concentrations $C_{i}^{\prime}$ are derived from the global atmospheric chemistry general circulation model ECHAM5/MESSy Atmospheric Chemistry (EMAC) (Jöckel et al., 2006). The EMAC simulation from which these parameters were obtained (B. Steil, personal communication, 2008) was performed with a horizontal resolution of T106 on a Gaussian grid (approximately $1.1^{\circ} \times 1.1^{\circ}$ in longitude and latitude, respectively) and 31 levels on a hybrid-pressure grid in the vertical. The output was archived every $5 \mathrm{~h}$. The monthly average values for April 2006 for the boundary layer of the grid covering Beijing are used for the initial concentrations, and the values of the neighboring grid to the west are used for the upwind concentrations. The initial $\left(y_{i}\right)$ and upwind $\left(y_{i}^{\prime}\right)$ mixing ratios of key gases, along with their deposition velocities, are listed in Table 2 . One may note that the values are lower in the upwind airmass than in the "box" for all species except $\mathrm{O}_{3}$. This is caused by the strong emission of $\mathrm{NO}_{\mathrm{x}}$ in the Beijing area, that results in lower ozone production efficiency in the "box" than in the upwind area, where there is less $\mathrm{NO}_{\mathrm{x}}$. This phenomenon has commonly been observed in and around North American and European cities (e.g. Kleinman et al., 1994; Kleinman, 2000). For the dust size distribution, we have used measurements over Northern China coastal areas during a dust storm episode in April 2006, which are assumed to be generally representative for the dust source regions in North China (Wang et al., 2008). The assumed upwind dust size distribution is shown in Fig. 2.

The emission fluxes of $\mathrm{CO}, \mathrm{NO}_{\mathrm{x}}, \mathrm{NMVOC}$ (non-methane volatile organic compound) and $\mathrm{SO}_{2}$ for the Beijing urban area are derived from the regional emission inventory of North China for the year 2006 (Zhao, 2007). The calculated emission rates of key gases are listed in Table 2 .

The dry deposition velocities of dust in different size classes are taken from Lee et al. (2005). They estimated the dry deposition velocity of Asian dust in spring of 2002 for 11 particle size bins with diameters ranging from 0.2 to $74 \mu \mathrm{m}$. The deposition velocities of gases are derived from the archived output of the EMAC simulation.

\subsection{Sensitivity simulations}

The wind speed and direction at $10 \mathrm{~m}$ above ground observed hourly at one meteorological station located in the Beijing urban area $\left(39.48^{\circ} \mathrm{N}, 116.28^{\circ} \mathrm{E}\right)$ show that in April 2006 the wind originating from the west has a average velocity of $2.2 \mathrm{~m} \mathrm{~s}^{-1}$ and a maximum velocity of $5.0 \mathrm{~m} \mathrm{~s}^{-1}$, while the wind from the northwest has an average velocity of $5.1 \mathrm{~m} \mathrm{~s}^{-1}$ and a maximum velocity of about $10.5 \mathrm{~m} \mathrm{~s}^{-1}$ (Fig. 3). To investigate the impact of dust which is imported to the Beijing region with different transport velocities, four cases are considered with different mixing time lengths. From slow to fast mixing, they are the "T16" case $(1 / f=16 \mathrm{~h})$, "T08" case $(1 / f=8 \mathrm{~h})$, "T04" case $(1 / f=4 \mathrm{~h})$ and "T02" case $(1 / f=2 \mathrm{~h})$, in which the exchange rate coefficients $f$ are 
Table 2. The initial $\left(y_{i}\right)$ and upwind $\left(y_{i}^{\prime}\right)$ mixing ratios, deposition velocities $\left(v_{d}\right)$ and emission rates $\left(B_{e}\right)$ of key gases.

\begin{tabular}{lllll}
\hline $\begin{array}{l}\text { gases } \\
\left(\mathrm{nmol} \mathrm{mol}^{-1}\right)\end{array}$ & $\begin{array}{l}y_{i} \\
\left(\mathrm{nmol} \mathrm{mol}^{-1}\right)\end{array}$ & $\begin{array}{l}y_{i}^{\prime} \\
\left(\mathrm{cm} \mathrm{s}^{-1}\right)\end{array}$ & $\begin{array}{l}v_{d} \\
\left(\mathrm{nmol} \mathrm{mol}^{-1} \mathrm{~s}^{-1}\right)\end{array}$ & $B_{e}$ \\
\hline $\mathrm{O}_{3}$ & 55.5 & 59.2 & 0.18 & 0 \\
$\mathrm{NO}_{2}$ & 8.6 & 5.7 & 0.13 & $4.3 \times 10^{-4}$ \\
$\mathrm{NO}$ & 1.3 & 0.9 & $6.3 \times 10^{-3}$ & $3.8 \times 10^{-3}$ \\
$\mathrm{CO}$ & 245.4 & 222.1 & 0 & 0.04 \\
$\mathrm{SO}_{2}$ & 19.8 & 13.8 & 0.19 & $1.3 \times 10^{-3}$ \\
$\mathrm{H}_{2} \mathrm{O}_{2}$ & 0.23 & 0.19 & 0.29 & 0 \\
$\mathrm{CH}_{4}$ & 1789.6 & 1787.8 & 0 & 0 \\
$\mathrm{HCHO}$ & 0.91 & 0.83 & 0.07 & $7.3 \times 10^{-5}$ \\
$\mathrm{CH}_{3} \mathrm{OH}$ & 2.13 & 1.97 & 0.06 & $1.4 \times 10^{-4}$ \\
\hline
\end{tabular}

$1.7 \times 10^{-5}, 3.5 \times 10^{-5}, 7.0 \times 10^{-5}$ and $1.4 \times 10^{-4}$ per second, respectively. According to Gurjar et al. (2008), the surface area of Beijing megacity is about $20000 \mathrm{~km}^{2}$, which would correspond to $\sim 150 \mathrm{~km}$ per side. However, this applies to the entire Beijing district; only considering the highly populated central district would be about $10 \%$ of this area, or about $50 \mathrm{~km}$ per side. If we take a length scale of $100 \mathrm{~km}$ as intermediate between these extremes, then we estimate corresponding mean horizontal wind speeds ranging from $1.7 \mathrm{~m} \mathrm{~s}^{-1}$ to $14 \mathrm{~m} \mathrm{~s}^{-1}$. Thus the T16 case is at the low end of the mean winds originating from the west or northwest, while the T02 case represents an extreme case of very strong inflow from upwind regions. The dust number concentration $d N$ of size bin $i$ at time step $t$ is calculated in two steps, first:

$d N_{t, i}=d N_{t-1, i}+\left(d N_{0, i}-d N_{t-1, i}\right) \cdot \Delta t \cdot f$

where $d N_{0, i}$ is the "upwind dust number concentration" derived from our observation data; $\Delta t$ is the time step interval length; $f$ is the exchange rate coefficient. This is followed by:

$d N_{t, i}=d N_{t, i} \cdot\left(1-\Delta t \cdot v_{d i} / Z_{p b l}\right)$

where $v_{d i}$ is the deposition velocity of size bin $i$, and $Z_{p b l}$ is the planet boundary layer height. Then the dust surface area concentration $d S_{t, i}$ is estimated by:

$d S_{t, i}=d N_{t, i} \cdot 4 \cdot \pi \cdot r_{i}^{2}$

where $r_{i}$ is the radius of the dust particle of size bin $i$. The combination of the increase in the exchange rate coefficient $f$ from the T16 case to the T02 case, and the larger $v_{d i}$ for the larger dust particles results in the dust distributions shown in Fig. 2.

The settings of these four cases are listed in Table 3. In each case, four simulations are performed: a simulation without dust (NO_DUST), a simulation with dust but only considering the heterogeneous reactions (DUST_H), a simulation with dust, but only considering a decrease of photolysis rates (DUST_J) and a simulation considering boththe

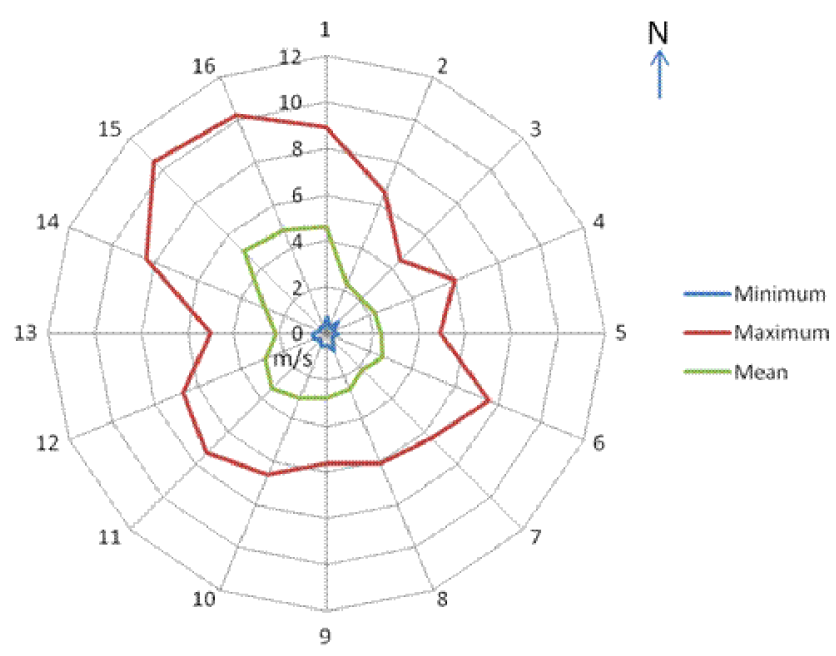

Fig. 3. Wind rose depicting the monthly average, minimum and maximum wind speed and direction during April 2006 at a station in the Beijing urban area $\left(39.48^{\circ} \mathrm{N}, 116.28^{\circ} \mathrm{E}\right)$.

heterogeneous reactions and a decrease of photolysis rates (DUST_H+J). Jeong et al. (2007) calculated a $47.3 \%$ decrease in the reactions having photolytic wavelengths in the UV $(210-380 \mathrm{~nm})$ at surface, for dust assumed to have a size distribution like that measured during ACE-Asia. In this study, an artificial 50\% decrease of all photolysis rates is used for the DUST $\mathbf{J}$ simulation and the DUST_H $+\mathbf{J}$ simulation, to examine the basic sensitivity in the context of dust over Beijing.

For the simulations, we allow a spinup time of $96 \mathrm{~h}$. This is sufficient to establish equilibrium with the upwind air mass for the long-lived tracers (e.g. CO and dust), even for the T16 case. In the following sections, analyses are based on the fifth simulation day, after equilibrium has been established.

The difference between the DUST_H and NO_DUST simulations isolates the influence of dust via heterogeneous reactions. The additional dust influence through photolysis 
Table 3. The settings used for the sensitivity simulations. The equivalent mean transport speed is estimated based on the assumption of a characteristic spatial scale for Beijing of $100 \mathrm{~km}$.

\begin{tabular}{lllll}
\hline & T16 & T08 & T04 & T02 \\
\hline Mixing time length $\lambda$ (hours) & 16 & 8 & 4 & 2 \\
Exchange rate coefficient $f\left(\mathrm{~s}^{-1}\right)$ & $1.7 \times 10^{-5}$ & $3.5 \times 10^{-5}$ & $7 \times 10^{-5}$ & $14 \times 10^{-5}$ \\
Mean transport speed $v\left(\mathrm{~m} \mathrm{~s}^{-1}\right)$ & 1.7 & 3.5 & 7 & 14 \\
\hline
\end{tabular}

Table 4. Gas phase reaction indices.

\begin{tabular}{ll}
\hline Reaction No. & Reaction \\
\hline R1 & $\mathrm{O}_{3}+h v \rightarrow \mathrm{O}_{2}+\mathrm{O}\left({ }^{3} \mathrm{P}\right)$ \\
R2 & $\mathrm{O}\left({ }^{3} \mathrm{P}\right)+\mathrm{O}_{2} \rightarrow \mathrm{O}_{3}$ \\
R3 & $\mathrm{O}_{3}+\mathrm{NO} \rightarrow \mathrm{NO}_{2}+\mathrm{O}_{2}$ \\
R4 & $\left.\mathrm{NO}_{2}+h v \rightarrow \mathrm{NO}_{+}{ }^{3} \mathrm{P}\right)$ \\
R5 & $\mathrm{NO}+\mathrm{HO} \mathrm{NO}_{2} \rightarrow \mathrm{NH}$ \\
R6 & $\mathrm{HONO}+h v \rightarrow \mathrm{NO}+\mathrm{OH}$ \\
R7 & $\mathrm{H} 2 \mathrm{O}+\mathrm{O}\left({ }^{1} \mathrm{D}\right) \rightarrow 2 \mathrm{OH}$ \\
R8 & $\mathrm{NO}+\mathrm{OH} \rightarrow \mathrm{HONO}$ \\
R9 & $\mathrm{NO}+\mathrm{OH} \rightarrow \mathrm{HNO}_{3}$ \\
R10 & $\mathrm{CO}+\mathrm{OH} \rightarrow \mathrm{H}+\mathrm{CO}_{2}$ \\
R11 & $\mathrm{SO}+\mathrm{OH}+\mathrm{O}_{2}+\mathrm{H}_{2} \mathrm{O} \rightarrow \mathrm{H}_{2} \mathrm{SO}_{4}+\mathrm{HO}_{2}$ \\
R12 & $\mathrm{NO}_{2}+\mathrm{O}_{3} \rightarrow \mathrm{NO}_{3}+\mathrm{O}_{2}$ \\
\hline
\end{tabular}

rates perturbation is represented by the difference between the DUST_J and NO_DUST simulations. These differences are discussed separately in the following section.

\section{Results}

\subsection{Influence of the exchange rate coefficient}

In this section, we will first discuss the influence due to mixing with upwind air mass (without the additional influence of dust), then in Sects. 3.2 and 3.3, we will consider the influence of dust via heterogeneous reactions and photolysis perturbation, respectively. The time series of the mixing ratios of $\mathrm{O}_{3}, \mathrm{NO}, \mathrm{NO}_{2}$ and the concentration of $\mathrm{OH}$ for $24 \mathrm{~h}$ (beginning at 00:00 of the fifth simulation day) are shown in Fig. 4 (black curves). A positive correlation with the exchange rate coefficient $f$ is found for the $\mathrm{O}_{3}$ mixing ratio and the $\mathrm{OH}$ concentration for the NO_DUST simulation, and a negative correlation is found for the $\mathrm{NO}$ and $\mathrm{NO}_{2}$ mixing ratios. We can understand the main factors contributing to these changes by examining the budget equations for each of these gases.

Considering the existence of the null cycle, Reactions (R1) and (R2) in Table 4, the Reaction (R3) is a dominant loss term for $\mathrm{O}_{3}$, from which the corresponding loss frequency will be much larger than the loss frequency due to heterogeneous removal of gases on dust. In order to better display the influence of heterogeneous removal on the tropospheric photochemistry in the following sections, only the family budget of $\mathrm{O}_{\mathrm{x}}$ (defined as $\left.\mathrm{O}_{3}+\mathrm{O}\left({ }^{3} \mathrm{P}\right)\right)$ will be analyzed. $\mathrm{O}\left({ }^{1} \mathrm{D}\right)$ is not included in $\mathrm{O}_{\mathrm{x}}$ due to its negligible effect (only $\sim 1 \%$ ). Similarly, the rapid photochemical equilibrium between $\mathrm{NO}$ and $\mathrm{NO}_{2}$, established by the Reactions (R3), (R4) and (R2), tends to dominate the individual budgets of $\mathrm{NO}$ and $\mathrm{NO}_{2}$, so that it is more enlightening to examine the budget of the family $\mathrm{NO}_{\mathrm{x}}$ (defined as $\mathrm{NO}+\mathrm{NO}_{2}$ ).

Considering that steady state has been reached, we have the equation:

$K_{t} \cdot\left(C_{i}^{\prime}-C_{i}\right)+B_{e}-K_{d} \cdot C_{i}+B_{c p}-K_{c l} \cdot C_{i}=0$,

where $C_{i}^{\prime}$ is the concentration of component $i$ in the upwind air masses, $C_{i}$ is the daily average concentration of component $i, K_{t}$ represents the exchange rate coefficient (i.e. " $f$ " in Eq., B1), $B_{e}$ is the source term due to direct emission into the box (i.e. " $J_{e} / Z_{p b l}$ " in Eq. 4 ), $K_{d}$ is the deposition coefficient (i.e. " $v_{d} / \mathrm{Z}_{p b l}$ " in Eq., 6), $B_{c p}$ is the daily average gross chemical production rate, and $K_{c l}$ is the daily average gross chemical loss frequency (so that $K_{c l} \cdot C_{i}$ is the daily average gross chemical loss term in the budget). Based on Eq. (10), we can solve for $C_{i}$ :

$C_{i}=\frac{K_{t} \cdot C_{i}^{\prime}+B_{e}+B_{c p}}{K_{t}+K_{c l}+K_{d}}$,

where $C_{i}^{\prime}, B_{e}$ and $K_{d}$ are fixed, while $B_{c p}$ and $K_{c l}$ change with $K_{t}$ because the tracer concentrations in the box are influenced by the inflowing upwind air mass.

Since the model is nearly in steady state, the change in $\mathrm{O}_{3}$ mixing ratio during the day (calculated as the mixing ratios at the end of day five minus the beginning of the fifth day) is very small, and a balance between its net production term (i.e. the transport process) and its net loss terms (i.e. the deposition process and the chemistry process) is reached, as listed in Table 5. The emission budget term is zero because no significant direct emission of $\mathrm{O}_{3}$ occurs. The transport process is the only production term of $\mathrm{O}_{3}$ and the corresponding major competitive process is the net chemical loss. It is qualitatively similar for $\mathrm{O}_{\mathrm{x}}$. The relationship between $\mathrm{O}_{\mathrm{x}}$ mixing ratio and these four processes in steady state is described in Eq. (11). For $\mathrm{O}_{\mathrm{x}}$, no emission is considered, so in 

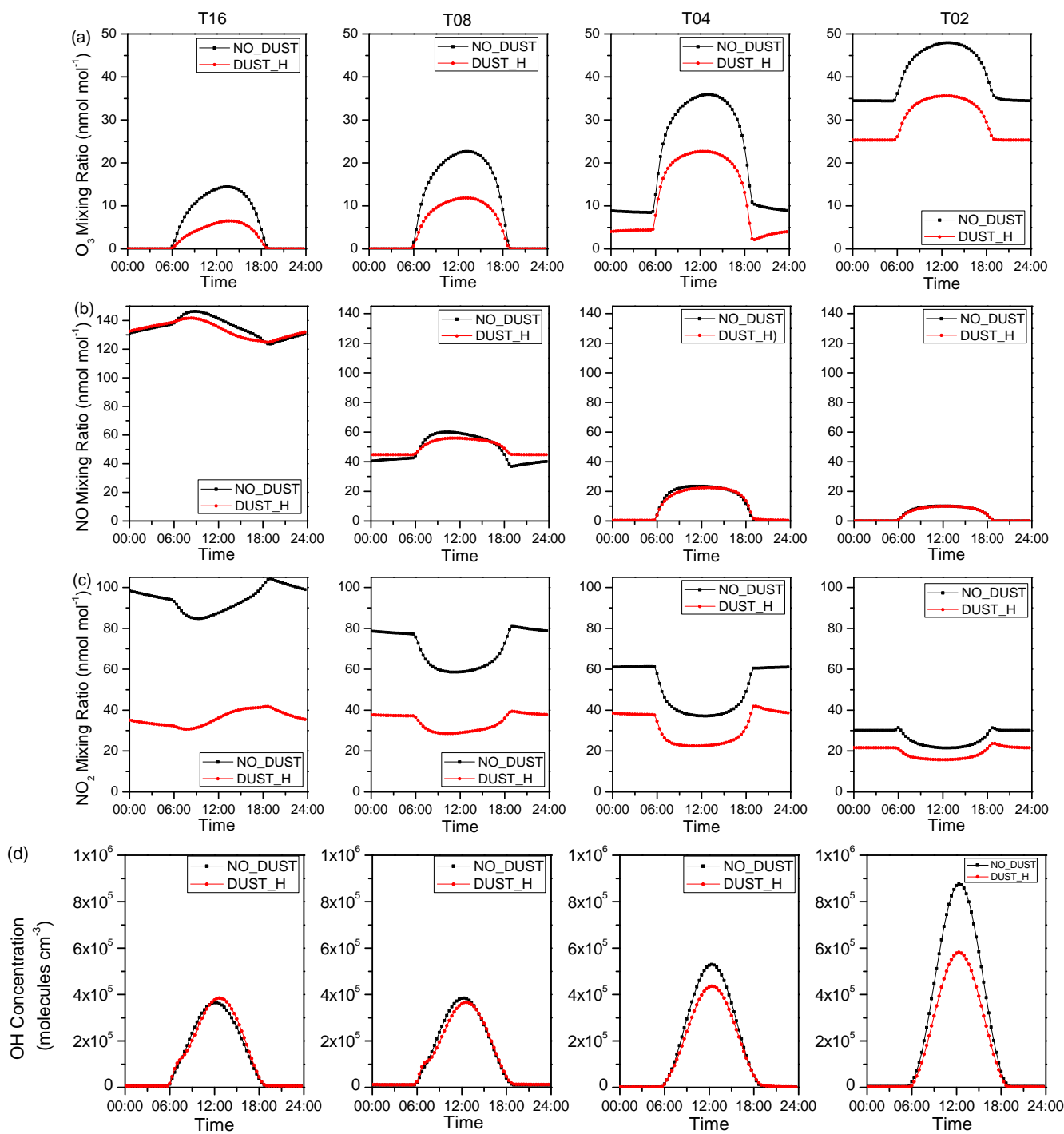

Fig. 4. Time series of (a) $\mathrm{O}_{3}$, (b) $\mathrm{NO}$ and (c) $\mathrm{NO}_{2}$ mixing ratios and (d) $\mathrm{OH}$ concentration for $24 \mathrm{~h}$ of the fifth simulation day. Different exchange rate coefficient cases are shown from left to right: "T16", "T08", "T04" and "T02". Results of the NO_DUST simulations and the DUST_H simulations are shown in black and red, respectively.

Table 5. Changes in $\mathrm{O}_{3}$ and $\mathrm{NO}_{\mathrm{x}}$ mixing ratios $(y)$ during the course of the 5th day of NO_DUST simulation, and factors contributing to the budget of each. (unit: $\mathrm{nmol} \mathrm{mol}^{-1}$ ).

\begin{tabular}{|c|c|c|c|c|c|c|c|c|}
\hline \multirow{2}{*}{$\begin{array}{l}\text { Tracer } \\
\text { Rate } \\
\text { Contribution } \\
\text { Process }\end{array}$} & \multicolumn{4}{|c|}{$\mathrm{O}_{3}$} & \multicolumn{4}{|c|}{$\mathrm{NO}_{\mathrm{x}}$} \\
\hline & T16 & T08 & T04 & T02 & T16 & T08 & T04 & T02 \\
\hline Change in $y$ & $1.6 \mathrm{E}-15$ & $3.9 \mathrm{E}-16$ & $-2.5 \mathrm{E}-16$ & $2.5 \mathrm{E}-10$ & 0.2 & 0.1 & 0.2 & -0.01 \\
\hline Transport & 80.6 & 150.1 & 231.7 & 230.9 & -341.4 & -350.7 & -356.4 & -355.5 \\
\hline Emission & 0 & 0 & 0 & 0 & 365.1 & 365.1 & 365.1 & 365.1 \\
\hline Deposition & -1.1 & -1.9 & -4.3 & -8.3 & -15.5 & -11.2 & -7.9 & -4.3 \\
\hline Chemistry & -79.5 & -148.2 & -227.4 & -222.6 & -7.9 & -3.2 & -0.7 & -5.4 \\
\hline
\end{tabular}



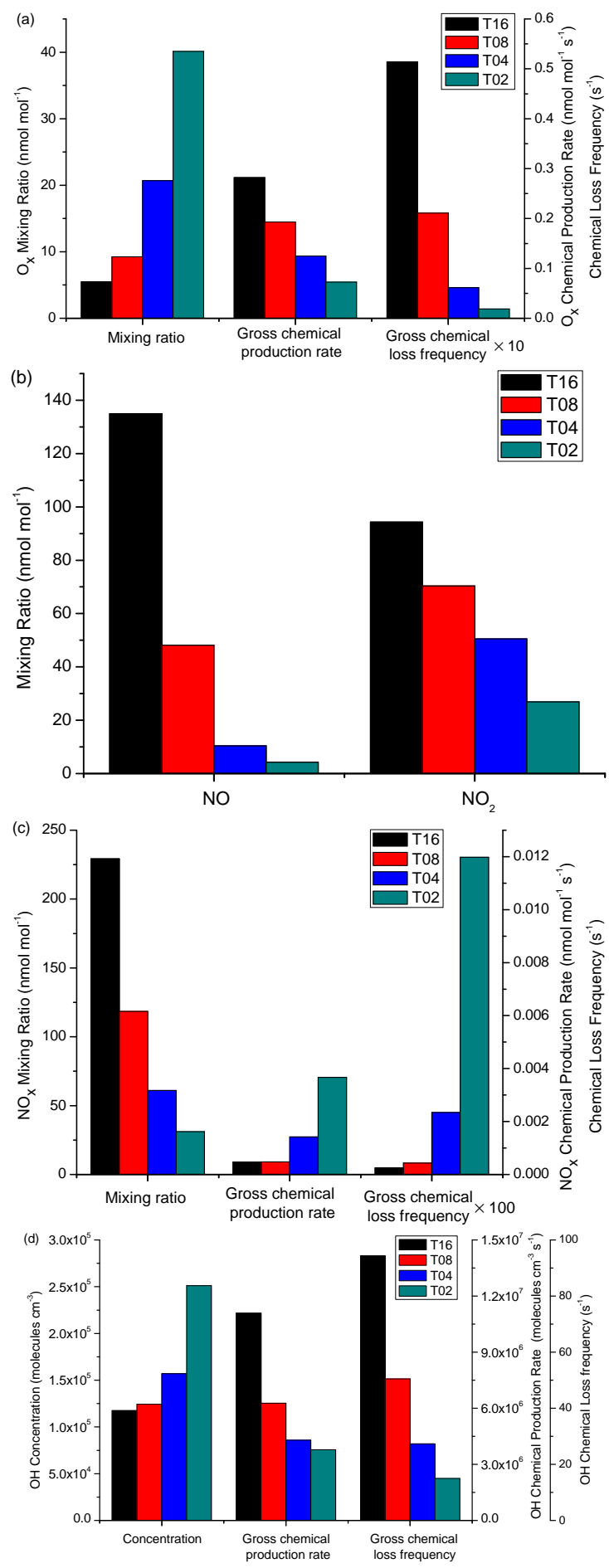

Fig. 5. The daily average mixing ratios of (a) $\mathrm{O}_{\mathrm{x}}$, (b) NO and $\mathrm{NO}_{2}$, (c) $\mathrm{NO}_{\mathrm{x}}$ and concentration of (d) OH for the NO_DUST simulations, and their gross chemical production rates $B_{c p}$ and gross chemical loss frequency $K_{c l}$. The chemical loss frequencies for $\mathrm{O}_{\mathrm{x}}$ and $\mathrm{NO}_{\mathrm{x}}$ are multiplied by 10 and 100 , respectively, for readability. For each term, the bar sequence from left to right is: "T16", "T08", "T04" and "T02".
Eq. (11), $B_{e}=0 . \quad y_{i}^{\prime}$ (and thus $C_{i}^{\prime}$ ) and $K_{d}$ are fixed for $\mathrm{O}_{3}$ as listed in Table 2 , and no physical process effects $\mathrm{O}\left({ }^{3} \mathrm{P}\right)$, while $B_{c p}$ and $K_{c l}$ change with the increasing $K_{t}$, as shown in Fig. 5a. From the T16 case to the T02 case, $K_{t}$ doubles each step from $1.7 \times 10^{-5} \mathrm{~s}^{-1}$ to $1.4 \times 10^{-4} \mathrm{~s}^{-1}$, while $\mathrm{B}_{c p}$ and $K_{c l}$ decrease in magnitude. Since no heterogeneous reactions on dust are included yet, the changes in $B_{c p}$ and $K_{c l}$ are due only to the changes in $\mathrm{NO}_{\mathrm{x}}$ and other gases. Although $K_{t}$ doubles each step, $B_{c p}$ and $K_{c l}$ are the dominating factors of the numerator and denominator of Eq. (11), respectively, which causes both the numerator and the denominator to decrease with the doubling $K_{t}$. We find that for each step from the $\mathrm{T} 16$ case to the $\mathrm{T} 02$ case, the relative decrease of the denominator is about 2 times larger than the relative decrease of the numerator. Consequently, the $\mathrm{O}_{\mathrm{x}}$ daily average mixing ratio approximately doubles when doubling $K_{t}$, although not exactly, as shown in Fig. 5a.

Similar to $\mathrm{O}_{3}$, the change in $\mathrm{NO}_{\mathrm{x}}$ mixing ratio during the day is very small and a balance between its production term (i.e. the emission process) and its loss terms (i.e. the transport process, the deposition process and the chemistry process) is reached, as listed in Table 5. However, different from $\mathrm{O}_{3}$, the emission process is the only production term of $\mathrm{NO}_{\mathrm{x}}$ and the corresponding major competitive process is the transport process. In Eq. (11), for $\mathrm{NO}_{\mathrm{x}}$, both the chemical production rate $B_{c p}$ and the chemical loss frequency $K_{c l}$ increase with the doubling $K_{t}$ as shown in Fig. 5c. Different from $\mathrm{O}_{\mathrm{x}}$, the local emission rate $B_{e}$ is the largest production term, and $K_{t}$ is the largest loss frequency, especially when the mixing is slow (i.e. smaller $K_{t}$ ). Both the numerator and the denominator of Eq. (11) increase with the doubling $K_{t}$. However, for each step from the T16 case to the T02 case, the relative increase of the denominator is larger than the relative increase of the numerator. Consequently, both the $\mathrm{NO}$ and $\mathrm{NO}_{2}$ daily average mixing ratios decrease with the doubling $K_{t}$, as seen in Fig. 5b.

As a short-lived radical, the $\mathrm{OH}$ concentration is determined only by its chemical budget. As shown in Fig. 6a, the major source terms of $\mathrm{OH}$ are Reactions (R5), (R6) and (R7). As already discussed, when the exchange rate coefficient increases, the $\mathrm{NO}$ and $\mathrm{NO}_{2}$ mixing ratios decrease. Thus, the rates of reactions R5 and R6 decrease with the increasing exchange rate coefficient $K_{t}$. This causes the decrease of the $\mathrm{OH}$ gross production rate with the increasing $K_{t}$, as seen in Fig. 5d. On the other hand, the major loss terms of $\mathrm{OH}$ are Reactions (R8), (R9), (R10) and (R11), due to the high mixing ratios of $\mathrm{NO}, \mathrm{NO}_{2}, \mathrm{CO}$, and $\mathrm{SO}_{2}$ from local emissions. The "Miscellaneous" loss term, which represents the loss of $\mathrm{OH}$ due to all other reactions, mostly with various hydrocarbons, is also important. It is worth noting that the Reaction (R11) plays an unusually large role over Beijing, due to the high $\mathrm{SO}_{2}$ mixing ratios originating largely from local emissions. Since the mixing ratios of $\mathrm{NO}, \mathrm{NO}_{2}, \mathrm{CO}$, $\mathrm{SO}_{2}$ and hydrocarbons decrease with the increasing $K_{t}$, the 
gross loss reaction frequency decreases in magnitude, as seen in Fig. 5d. We find that the relative decrease in the gross loss frequency is larger than the relative decrease in the gross production rate. As a result, the daily average $\mathrm{OH}$ concentration increases with increasing $K_{t}$, as seen in Fig. 5d.

\subsection{Influence of heterogeneous uptake on dust}

The influence of dust via heterogeneous reactions is discussed in this section. First, following up on the discussion in the previous section, for the DUST_H simulations, when $K_{t}$ increases, the tendencies of the $\mathrm{O}_{\mathrm{x}}$ and $\mathrm{NO}_{\mathrm{x}}$ mixing ratios are qualitatively similar to those for the NO_DUST simulations discussed in Sect. 3.1. However, the tendency of the $\mathrm{OH}$ concentration is different: it stays nearly constant, decreasing slightly from the T16 case to the T08 case, then increasing again to the $\mathrm{T} 02$ case. The $\mathrm{OH}$ concentration results from a delicate balance between loss and production terms as discussed above. Introducing losses of several gases on dust, especially $\mathrm{NO}_{2}$ and $\mathrm{SO}_{2}$, shifts this balance so that $\mathrm{OH}$ responds differently to $K_{t}$ in the DUST_H case than in the NO_DUST case.

The overall effect of introducing the heterogeneous dust reactions is to decrease the $\mathrm{O}_{\mathrm{x}}$ mixing ratio, as seen in Fig. 7a. The change ranges from -2.5 to $-18.4 \mathrm{nmol} \mathrm{mol}^{-1}$, and is larger for faster mixing in of upwind air masses (i.e. greater $K_{t}$ ). This translates into a large relative change (in percentage, calculated as $100 \times\left(\right.$ DUST_H-NO_DUST)/NO_DUST) in $\mathrm{O}_{\mathrm{x}}$, ranging from $-44 \%$ to $-55 \%$, which increases in magnitude slightly from the T16 case to the T04 case, then decreases in magnitude slightly to the T02 case. In order to understand how the various changes due to the inclusion of heterogeneous dust reactions contribute to this decrease in $\mathrm{O}_{\mathrm{x}}$, as well as for other gases (discussed below), we can analyze the budget equations for the DUST_H and NO_DUST cases more closely. Based on Eq. (11), the heterogeneous influence on the tracer daily average concentration is represented as (for any species $i$, leaving out the subscript here for readability):

$$
\Delta C=\frac{\Delta B_{c p}-\Delta K_{c l} \cdot C_{(\text {NO_DUST })}}{\left(K_{t}+K_{c l \text { (DUST_H })}+K_{d}\right)} .
$$

The derivation of Eq. (12) is explained in Appendix B. Since the denominator in Eq. (12) is always positive, this indicates that the balance between the changes in the gross chemical production rate $B_{c p}$ and the gross chemical loss frequency $K_{c l}$, determine whether the heterogeneous reactions will cause an increase or decrease in the daily average mixing ratio. Since the direct influence of dust due to heterogeneous uptake of $C$ is included in the chemical loss frequency, $K_{c l}$, and its change, $\Delta K_{c l}$, one would expect this to result in a tendency for the mixing ratios of most gases to decrease, as seen to be the case for $\mathrm{O}_{\mathrm{x}}$, though this is not always the case, as shown below. Equation (12) also shows that, all else being

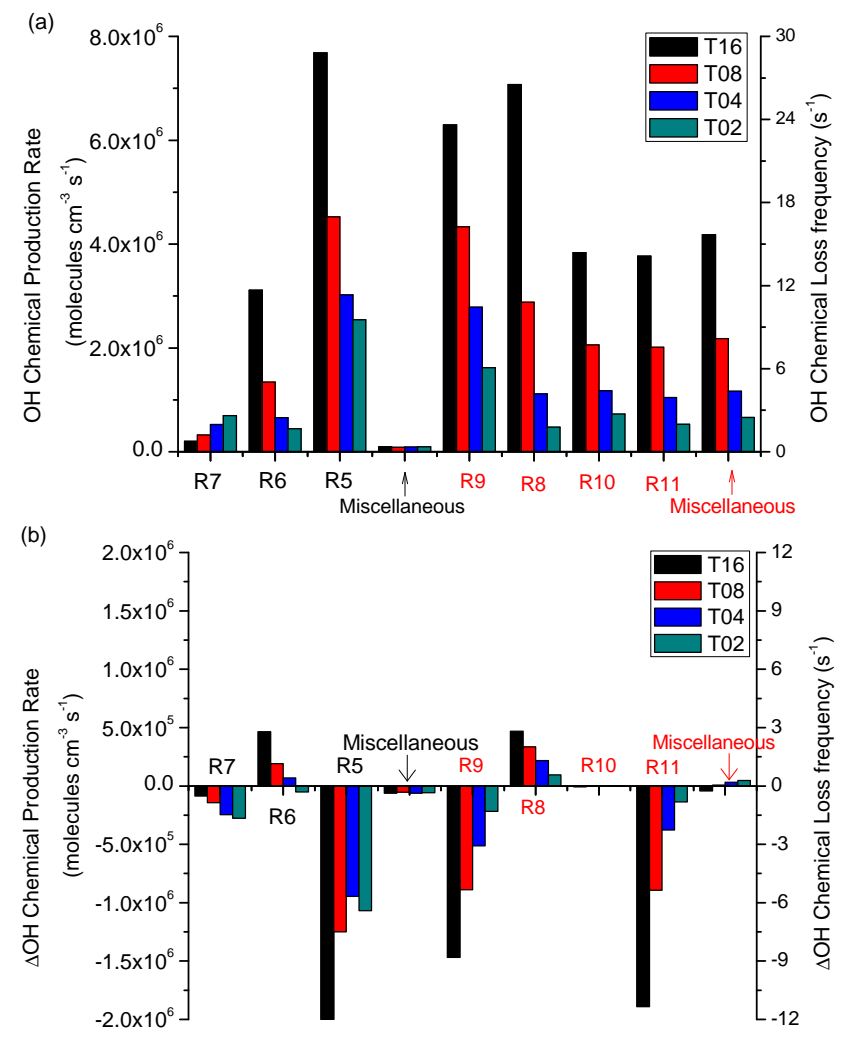

Fig. 6. (a) The daily average chemical production rates (labels in black) and chemical loss frequencies (labels in red) of $\mathrm{OH}$ for the NO_DUST simulation. (b) The differences between the DUST_H and NO_DUST simulations (DUST_H-NO_DUST). "Miscellaneous" represents the sum of all the other source or loss terms. The bar sequence is the same as in Fig. 5. The reactions are listed in Table 4.

equal, the change in $C$ becomes smaller as the rate of mixing $\left(K_{t}\right)$ becomes larger (in comparison to $K_{c l}($ DUST_H) $)$.

As shown in Fig. 7a, for each of the four exchange rate coefficient cases, the gross chemical production rate $\left(B_{c p}\right)$ decreases when the dust reactions are included. This is mainly due to the decrease in the $\mathrm{NO}_{2}$ mixing ratio (Fig. $7 \mathrm{~b}$ ). The relative change in $B_{c p}$ is substantial, ranging from about $-37 \%$ (T16) to $-21 \%$ (T02). On the other hand, as $K_{t}$ increases from the T16 case to the T02 case, the dust surface area concentration also increases as shown in Fig. 2. Consequently, the $\mathrm{O}_{\mathrm{x}}$ loss frequency due to the heterogeneous removal (HR1) also increases, as shown in Fig. 7a. This, however, is small compared to the change in $K_{c l}$, also shown in Fig. 7a. The relative change in $K_{c l}$ is substantial, ranging from $13 \%$ (T16) to $61 \%$ (T04), as shown in Fig. 8a, and is mostly governed by the change in NO via the Reaction (R3) which increases substantially as shown in Fig. 7b. Because the relative increase of $\mathrm{NO}$ is largest in the T04 case, it is thus the T04 case, instead of the T02 case, which has the largest relative increase in the $K_{c l}$ of $\mathrm{O}_{\mathrm{x}}$. This is part of another 

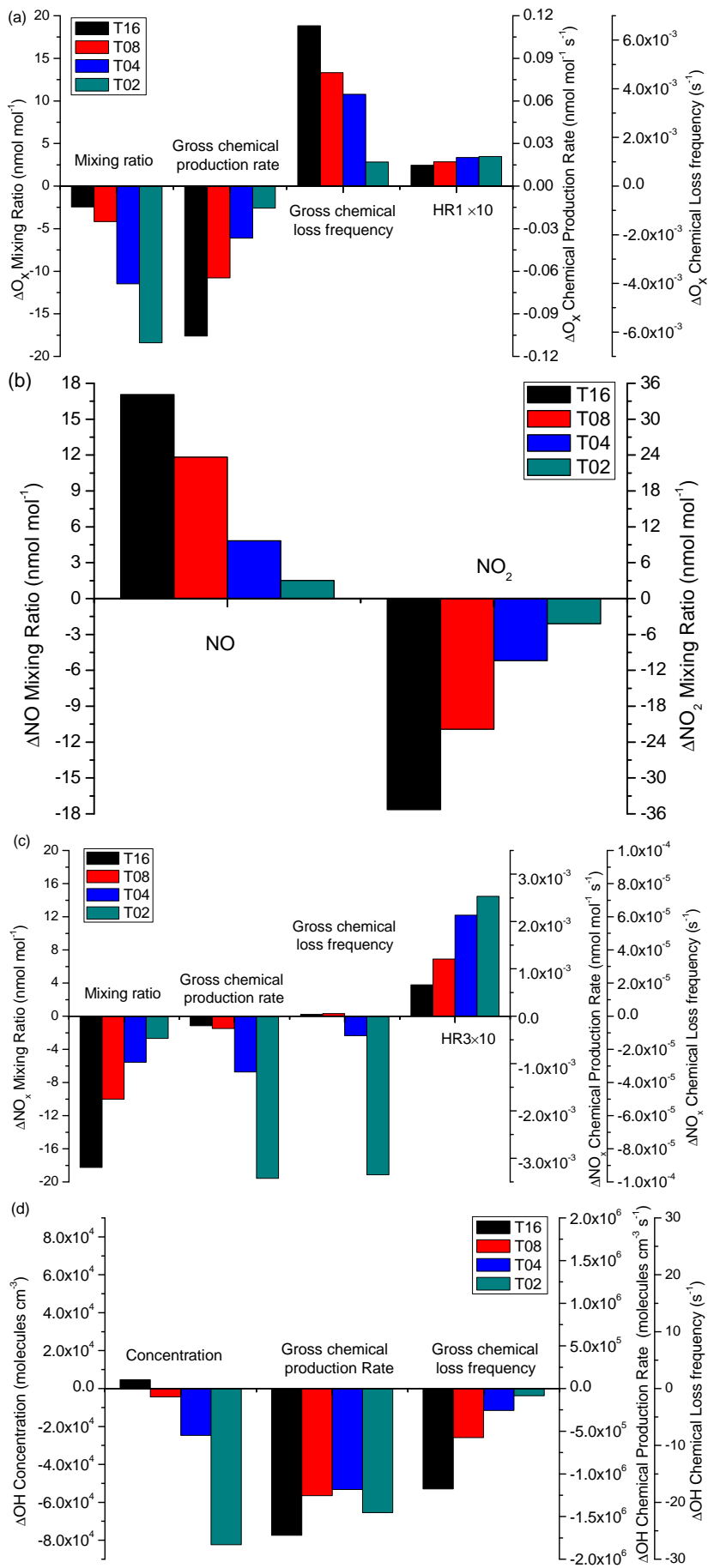

Fig. 7. Differences of the daily average mixing ratios and the gross chemical production rates $B_{c p}$ and the gross chemical loss frequencies $K_{c l}$ of (a) $\mathrm{O}_{\mathrm{x}}$, (b) $\mathrm{NO}$ and $\mathrm{NO}_{2}$ (c) $\mathrm{NO}_{\mathrm{x}}$, and (d) $\mathrm{OH}$, between the DUST_H and NO_DUST simulations (DUST_H-NO_DUST). The bar sequence is the same as in Fig. 5.

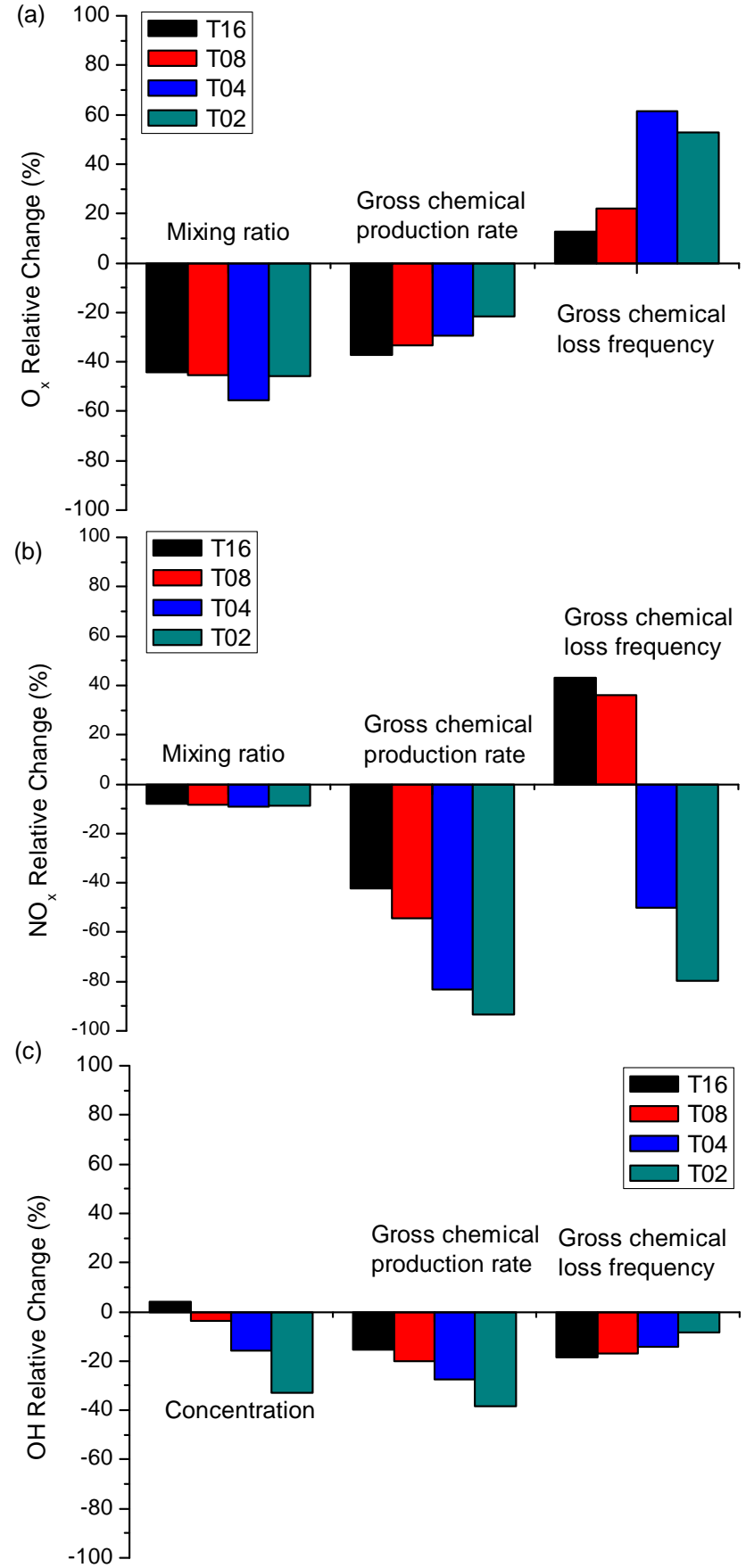

Fig. 8. Relative differences of the daily average mixing ratios and the gross chemical production rates $B_{c p}$ and the gross chemical loss frequencies $K_{c l}$ of (a) $\mathrm{O}_{\mathrm{x}}$, (b) $\mathrm{NO}_{\mathrm{x}}$, and (c) $\mathrm{OH}$ due to the heterogeneous dust reactions. The bar sequence is the same as in Fig. 5. 
null cycle (Reactions R3, R4 and R2), which can principally be removed by extending the definition of $\mathrm{O}_{\mathrm{x}}$ to include $\mathrm{NO}_{2}$ (Crutzen and Schmailzl, 1983). When the budget of $\mathrm{O}_{\mathrm{x}}$ with this broader definition as $\mathrm{O}_{3}+\mathrm{O}\left({ }^{3} \mathrm{P}\right)+\mathrm{NO}_{2}+\mathrm{O}\left({ }^{1} \mathrm{D}\right)$ is analyzed, the strong direct effect of the heterogeneous reaction becomes apparent. For example, in the T08 case, the loss frequency of the heterogeneous uptake (HR1+HR3) is $1.6 \times 10^{-5} \mathrm{~s}^{-1}$ and the $\Delta K_{c l}$ is $1.2 \times 10^{-5} \mathrm{~s}^{-1}$, which corresponds to a relative increase of $125 \%$ (The value of $K_{c l}$ in the NO_DUST run is $\left.0.96 \times 10^{-5} \mathrm{~s}^{-1}\right) . \Delta K_{c l}$ is a bit smaller than the loss frequency of the heterogeneous uptake, due to the negative response of some gas phase reactions (e.g. the loss frequency of the reaction $\mathrm{NO}_{2}+\mathrm{O}_{3} \rightarrow \mathrm{NO}_{3}+\mathrm{O}_{2}$ Reaction (R12) decreases by $3.3 \times 10^{-6} \mathrm{~s}^{-1}$ ). Since, however, $\mathrm{O}_{3}$ and $\mathrm{NO}_{\mathrm{x}}$ more closely correspond to the quantities that are normally reported in observations and other modeling studies, we will mostly employ these standard definitions here, rather than the extended $\mathrm{O}_{\mathrm{x}}$ definition.

The overall effect of introducing the heterogeneous dust reactions is to decrease the $\mathrm{NO}_{\mathrm{x}}$ mixing ratio, as seen in Fig. 7c. The decrease ranges from -18 to $-2.7 \mathrm{nmol} \mathrm{mol}^{-1}$, and is smaller for faster mixing in of upwind air masses (i.e. greater $K_{t}$ ). This translates into a relative decrease ranging from $-8 \%$ to $-9 \%$ (Fig. 9b), which changes slightly with increasing values of $K_{t}$. For each of the four exchange rate coefficient cases, the gross chemical production rate $\left(B_{c p}\right)$ decreases when the dust reactions are included. This is mainly due to the decrease in other gases, e.g. $\mathrm{NO}_{3}$ and $\mathrm{N}_{2} \mathrm{O}_{5}$. The relative decrease in $B_{c p}$ is substantial, increasing in magnitude from about $-42 \%$ (T16) to $-93 \%$ (T02). From the T16 case to the T02 case, the $\mathrm{NO}_{\mathrm{x}}$ loss frequency due to the heterogeneous removal (HR3) increases due to the increasing dust surface area concentration, as shown in Fig. 7c. This translates into a substantial relative change in the gross chemical loss frequency $K_{c l}$, which is positive for T16 and T08 and negative for the other two cases, as shown in Fig. 8b. This is because the change in $K_{c l}$ is also influenced by the decrease in $\mathrm{NO}_{3}$ via the reaction $\mathrm{NO}_{3}+\mathrm{NO}_{2} \rightarrow \mathrm{N}_{2} \mathrm{O}_{5}$, which changes from $-2.7 \times 10^{-8} \mathrm{~s}^{-1}$ in the T16 case to $-9.0 \times 10^{-5} \mathrm{~s}^{-1}$ in the T02 case, and is larger in magnitude than the increase in the loss frequency of the heterogeneous removal HR3 in the T04 and T02 cases.

As shown in Figs. 7d and 8c, the overall influence of the heterogeneous dust reactions is to increase the $\mathrm{OH}$ concentration in the $\mathrm{T} 16$ case, and reduce $\mathrm{OH}$ in the other three cases. The corresponding relative change ranges from $4 \%$ in the $\mathrm{T} 16$ case to $-33 \%$ in the T02 case. On the whole, this is due to the balance in the production and loss terms in the chemical budget (see Eq. 11), especially given the short lifetime of $\mathrm{OH}$. For all four cases, both the gross production rate $B_{c p}$ and the gross loss frequency $K_{c l}$ decrease. However, as $K_{t}$ increases from the T16 case to the T02 case, the relative change in $B_{c p}$ increases in magnitude and the relative change in $K_{c l}$ decreases in magnitude. In the T16 case, the relative change in $B_{c p}$ is smaller in magnitude than in $K_{c l}$, leading

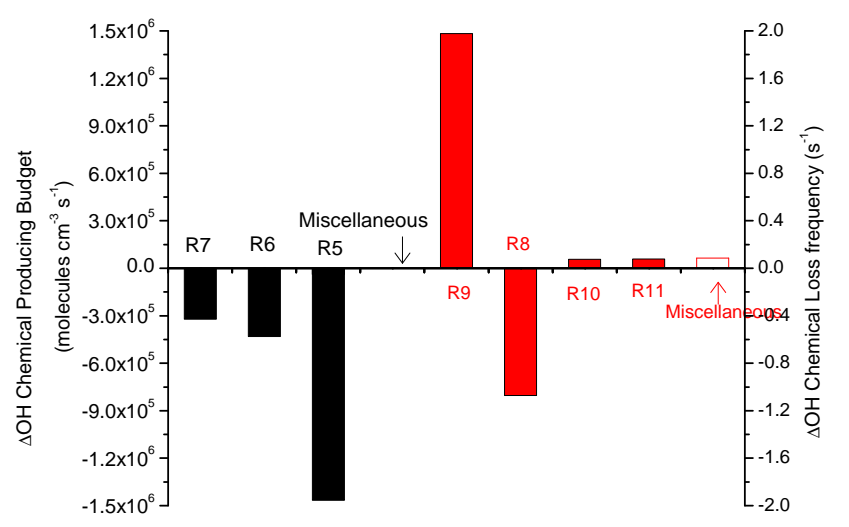

Fig. 9. Differences of the daily average chemical production budgets (black bars) and chemical loss frequencies (red bars) of $\mathrm{OH}$, between the DUST_J and NO_DUST simulations (DUST_J-NO_DUST) in the T04 case. "Miscellaneous" (hollow bars) represents the sum of all the other source or loss terms. The reactions are listed in Table 4.

to the increase in $\mathrm{OH}$ concentration. In the other three cases the relative change in $B_{c p}$ is larger in magnitude than in $K_{c l}$, leading to the decrease in $\mathrm{OH}$ concentration. For the $\mathrm{T} 08$, $\mathrm{T} 04$ and $\mathrm{T} 02$ cases, the relative change in $\mathrm{OH}$ concentration increases in magnitude as $K_{t}$ increases. The main reactions responsible for these changes are depicted in Fig. 6d. The change in the gross production rate $B_{c p}$ is mainly due to the reaction $\mathrm{R} 5$, because of the strong local buildup of $\mathrm{NO}_{\mathrm{x}}$ (up to about $150 \mathrm{nmol} \mathrm{mol}^{-1}$ of NO in the T16 case) caused by the strong urban emissions. The change in the gross loss frequency $K_{c l}$ is primarily due to the reactions R9 and R11, especially strongly in the $\mathrm{T} 16$ case, again due to the buildup of high local pollution levels, in this case $\mathrm{NO}_{2}$ and $\mathrm{SO}_{2}$, where the latter can be expected to be particularly applicable to Chinese megacities (Tang et al, 2004). On the whole, this shows that the $\mathrm{OH}$ response to dust reactions is complex and will be difficult to predict for other cities without model simulations (box or 3-D) applicable to their specific conditions.

\subsection{Photolysis influence}

In order to investigate the influence of dust via photolysis rate perturbations, the simulation DUST $\mathrm{J}$ is performed for the T04 case with an artificial 50\% decrease of all photolysis rate coefficients. It is important to note that the actual change in photolysis rates due to dust will vary from species to species, due to the wavelength-dependent effects of dust particles on the actinic flux; the approach here is only meant to establish an order-of-magnitude estimate of this effect, as an indicator of whether or not it is worth continued investigation for characterizing the effects of dust on chemistry in Beijing. The differences in the daily ( $24 \mathrm{~h}$ ) mean mixing ratios and the gross chemical production budgets and loss frequencies of $\mathrm{O}_{\mathrm{x}}, \mathrm{NO}_{\mathrm{x}}$ and $\mathrm{OH}$ between the DUST_J and NO_DUST 
Table 6. The differences calculated as DUST_J-NO_DUST of the daily average mixing ratios ( $y$ )and the gross chemical production rates $\left(B_{c p}\right)$ and the gross chemical loss frequencies $\left(K_{c l}\right)$ of $\mathrm{O}_{\mathrm{x}}, \mathrm{NO}_{\mathrm{x}}$ and $\mathrm{OH}$ due to the decrease of photolysis rate coefficients for the $\mathrm{T} 04$ case. The relative differences calculated as (DUST_J-NO_DUST)/NO_DUST are shown in parentheses. For OH, the concentration $C$ is shown instead of the mixing ratio $y$.

\begin{tabular}{llll}
\hline & $y$ & $B_{c p}$ & $K_{c l}$ \\
\hline $\mathrm{O}_{\mathrm{x}}$ & $-3.7 \mathrm{nmol} \mathrm{mol}^{-1}(-17.8 \%)$ & $-0.05 \mathrm{nmol} \mathrm{mol}^{-1} \mathrm{~s}^{-1}(-42.3 \%)$ & $-1.8 \times 10^{-3} \mathrm{~s}^{-1}(-28.6 \%)$ \\
$\mathrm{NO}_{\mathrm{x}}$ & $0.3 \mathrm{nmol} \mathrm{mol}^{-1}(0.5 \%)$ & $-1.5 \times 10^{-4} \mathrm{nmol} \mathrm{mol}^{-1} \mathrm{~s}^{-1}(-7.5 \%)$ & $-2.4 \times 10^{-6} \mathrm{~s}^{-1}(-10.1 \%)$ \\
$\mathrm{OH}$ & $-8.5 \times 10^{4} \mathrm{molecules} \mathrm{cm}^{-3}(-54.2 \%)$ & $-2.2 \times 10^{6}$ molecules cm$^{-3} \mathrm{~s}^{-1}(-52.3 \%)$ & $1.1 \mathrm{~s}^{-1}(4.2 \%)$ \\
\hline
\end{tabular}

Table 7. The linearly summed influences (calculated as DUST_H-NO_DUST+DUST_J-NO_DUST) and the nonlinearly combined influences (calculated as DUST_H+J-NO_DUST) of dust on the daily average mixing ratios $y$ of $\mathrm{O}_{\mathrm{x}}, \mathrm{NO}_{\mathrm{x}}$ and the daily average concentration $C$ of $\mathrm{OH}$ through the heterogeneous removal reactions and the photolysis rates decrease for the T04 case. The relative influences (i.e. the influences normalized by NO_DUST) are shown in parentheses.

\begin{tabular}{llll}
\hline & $\mathrm{O}_{\mathrm{x}} \mathrm{nmol} \mathrm{mol}^{-1}$ & $\mathrm{NO}_{\mathrm{x}} \mathrm{nmol} \mathrm{mol}^{-1}$ & $\mathrm{OH}$ molecules cm \\
\hline Linear & $-15.2(-73.3 \%)$ & $-5.2(-8.6 \%)$ & $-1.1 \times 10^{5}(-69.9 \%)$ \\
Nonlinear & $-13.2(-63.8 \%)$ & $-5.9(-9.6 \%)$ & $-9.6 \times 10^{4}(-61.1 \%)$ \\
\hline
\end{tabular}

simulations and the relative differences are listed in Table 6. This artificial photolysis rate perturbation causes a large relative decrease in $\mathrm{OH}(-54 \%)$ and $\mathrm{O}_{\mathrm{x}}(-18 \%)$, respectively, while only a small relative increase $(0.5 \%)$ is computed for $\mathrm{NO}_{\mathrm{x}}$.

When the photolysis rate coefficients are reduced, the rate of the reaction $\mathrm{R} 4$ decreases, and thus the $B_{c p}$ of $\mathrm{O}_{\mathrm{x}}$ decreases. On the other hand, the values of $K_{c l}$ for $\mathrm{O}_{\mathrm{x}}$ also decrease due to the change in NO mixing ratio $\left(-2.8 \mathrm{nmol} \mathrm{mol}^{-1}\right)$. Since the relative decrease in the $B_{c p}$ is larger than the relative decrease in the $K_{c l}$, and based on Eq. (12), the $\mathrm{O}_{\mathrm{x}}$ mixing ratio decreases due to the dust photolysis perturbation.

For $\mathrm{NO}_{\mathrm{x}}$, as discussed in Sect. 3.1, the numerator and denominator of Eq. (11) are dominated by the emission rate $B_{e}$ and the exchange rate coefficient $K_{t}$, respectively. As a result, although $B_{c p}$ decreases by $7.5 \%$ and $K_{c l}$ decreases by $10.1 \%$, the numerator and denominator of Eq. (11) do not change significantly. Consequently, $\mathrm{NO}_{\mathrm{x}}$ mixing ratio only decreases slightly.

As shown in Fig. 9, all the production terms of $\mathrm{OH}$ decrease due to the decrease in the photolysis rate coefficients, so the $B_{c p}$ of $\mathrm{OH}$ decreases. On the other hand, the small increase in the $\mathrm{OH}$ loss frequency is due to the balance between large changes in the reactions with NO (Reaction R8) and $\mathrm{NO}_{2}$ (Reaction $\mathrm{R} 9$ ), with the latter dominating slightly. This combination results in the large decrease in the $\mathrm{OH}$ concentration.

In real conditions, the effects of dust on the tropospheric chemistry through the heterogeneous removal and the photolysis perturbations will act simultaneously. To test the de- gree of nonlinearity, we can compare the results from the DUST $H+J$ simulation to the sum of individual changes in the DUST_H and the DUST J simulations, as shown in Table 7. We find that the differences (i.e., the nonlinearities) are small, with the nonlinearly combined influences of dust on $\mathrm{O}_{\mathrm{x}}$ and $\mathrm{OH}$ being somewhat smaller than the linearly summed influences: the differences in the relative influences are $9.5 \%$ for $\mathrm{O}_{\mathrm{x}} 8.8 \%$ for $\mathrm{OH}$, and only $1 \%$ for $\mathrm{NO}_{\mathrm{x}}$.

\subsection{Uncertainties}

As described in Appendix A, due to the different types of mineral dust and different methodologies used in laboratory experiments, the measured accommodation or uptake coefficients have large uncertainties, in some cases several orders of magnitude. This can lead to large uncertainties in the calculated heterogeneous removal influence of dust. We can make use of the numerical model to examine the relative significance of the influence of each heterogeneous removal reaction and the uncertainty in the results. For this purpose, simulations in the T08 case have been performed in which one removal reaction is calculated individually with either the "Lower Limit" or "Upper Limit" coefficient from Table 1, and all the other removal reactions are calculated with the "Best Guess" coefficients. The differences in the tracer mixing ratios calculated with the "Upper Limit" and "Lower Limit" coefficients are normalized by the tracer mixing ratio calculated without dust considered, i.e. $\frac{y_{\text {DUST_H }}\left(\gamma_{\text {Upper }}\right)-y_{\text {DUST_H }}\left(\gamma_{\text {Lower }}\right)}{y_{\text {NO }} \text { DUST }}$, and the results are compared in Fig. 10. The absolute differences, i.e. $y_{\text {DUST_H }}\left(\gamma_{\text {Upper }}\right)-y_{\text {DUST_H }}\left(\gamma_{\text {Lower }}\right)$, are shown in 
Appendix $\mathrm{C}$ for reference. The uncertainties are negative for the gases which are reduced due to the heterogeneous removals, and positive for the gases which are increased due to the heterogeneous removal. Although the cumulative effect of all reactions can be different, some insight into the effect of each single reaction is provided by this approach.

For all gases which are heterogeneously removed, the self-removal results in the largest uncertainty (e.g. $-49.2 \%$ for $\mathrm{O}_{3},-75.7 \%$ for $\mathrm{NO}_{2},-46.6 \%$ for $\mathrm{HNO}_{3},-92.2 \%$ for $\mathrm{HCHO},-64.3 \%$ for $\mathrm{CH}_{3} \mathrm{OH}$ and $-93.3 \%$ for $\mathrm{SO}_{2}$ ), except for $\mathrm{OH}$ and $\mathrm{HO}_{2}$, for which the largest uncertainties come from the heterogeneous removal of $\mathrm{NO}_{2}$. We find that the heterogeneous removal of $\mathrm{NO}_{2}$ is particularly important, because it results in significant uncertainties not only in itself, but also in $\mathrm{OH}(340.4 \%)$ and $\mathrm{HO}_{2}(365.6 \%)$. Moreover, the heterogeneous removals of $\mathrm{HCHO}$ and $\mathrm{O}_{3}$ also have fartherreaching effects, causing uncertainties in the $\mathrm{OH}$ concentration of $-54.8 \%$ and $45.0 \%$, respectively; furthermore, the heterogeneous removal of $\mathrm{HCHO}$ results in an uncertainty of $-38.4 \%$ in $\mathrm{HO}_{2}$ concentration.

If we instead normalize by the tracer mixing ratio calculated with the "Best Guess" coefficients, i.e. $\frac{y_{\text {DUST_H }}\left(\gamma_{\text {Upper }}\right)-y_{\text {DUST_H}}\left(\gamma_{\text {Lower }}\right)}{y_{\text {DUST_H}}\left(\gamma_{\text {Best_Guess }}\right)}$, we compute larger uncertainties (e.g. $-89.8 \%$ for $\mathrm{O}_{3}$ ) and some with extremely large values (e.g. $-558552 \%$ for $\mathrm{HNO}_{3}$ ). This is because introduction of the heterogeneous removal reactions (i.e., the DUST_H "Best Guess" case) already decreases these tracer mixing ratios as discussed in Sect. 3.2, even to extremely low values for some tracers like $\mathrm{HNO}_{3}$ due to their rapid uptake. The uncertainties computed with this manner are also shown in Appendix D for reference.

On the whole, the results clearly indicate that the uncertainty in the uptake coefficients result in large uncertainties for the influence of dust under polluted conditions, and point towards where future work should be focused.

The chemical reaction scheme used in this study includes detailed chemistry of organic species with up to four Catoms and isoprene. Uncertainties are expected due to the limited VOC species considered in the model, since aromatic species and other VOC species with more than four $\mathrm{C}$-atoms are also important for the gas-phase photo oxidation chemistry in an urban area. To partially account for this, in the model simulations discussed above we have already distributed the missing VOC (in terms of mass of C) as a surrogate amongst the lower hydrocarbons (including Ethylene, Ethane, Propene, Propane, Butane, Acetaldehyde, Acetone, Acetic acid, Methanol, Methanal, Formic acid and Methyl Ethyl Ketone). To gain a further impression of the uncertainty introduced by this surrogate treatment of the missing VOC, here we perform two additional sensitivity runs in which we redistribute a large fraction of the total VOC into two surrogate species, $\mathrm{C}_{3} \mathrm{H}_{6}$ and $\mathrm{C}_{4} \mathrm{H}_{10}$ with different reactivities and oxidation pathways (and thus effects on ozone and $\mathrm{OH}$ ). For this sensitivity study, we have chosen to re-

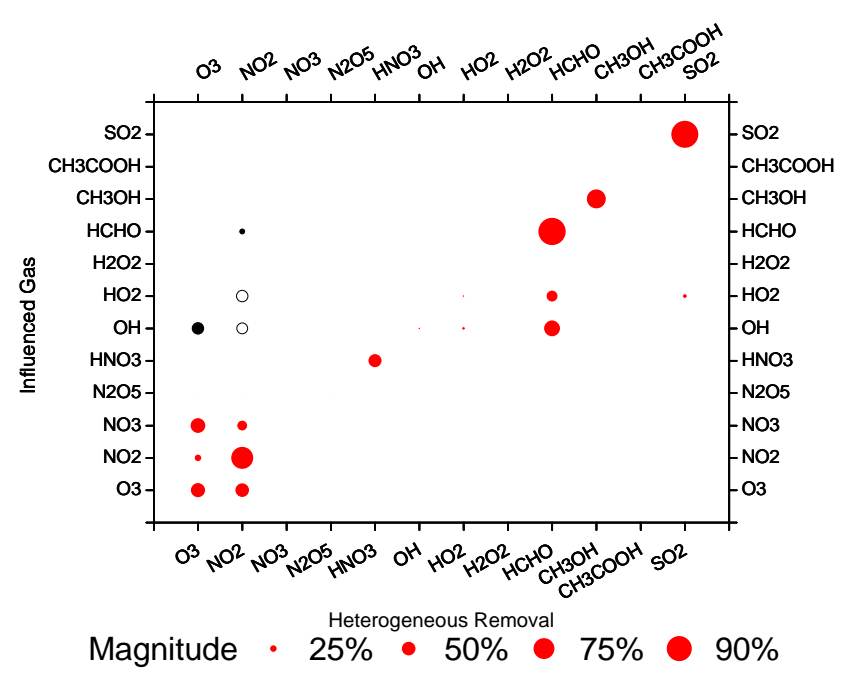

Fig. 10. Uncertainties of the tracer mixing ratios caused by each heterogeneous removal reaction. The colors red and black represent negative and positive values, respectively. Hollow circle represents the values scaled by 0.1 . Corresponding values are shown in Table 8 .

distribute $25 \%$ of the total VOC in this manner, which we have chosed based on the result of Shao et al. (2009) that the aromatics and the C5 alkenes contributed $17 \%$ and $7 \%$, respectively, to the $\mathrm{OH}$ radical loss rate of VOCs in the urban area of Beijing in 2006. "S1" and "S2" are used to represent the results from simulations with the VOC emissions redistributed into $\mathrm{C}_{3} \mathrm{H}_{6}$ and $\mathrm{C}_{4} \mathrm{H}_{10}$, respectively. They are compared to the results from Sect. 3.2 (denoted as "S0"), as listed in Table 9. We find that, on the whole, these drastic changes in the emissions only cause relatively small changes in the result, of the order of $10 \%$ or less for $\mathrm{O}_{3}$, and $20 \%$ or less for $\mathrm{OH}$, with the one major exception of the effect of heterogeneous dust reactions on $\mathrm{OH}$, which is found to be about three times as large for the $\mathrm{S} 1$ case as in the results discussed above (S0 case). Since NO_DUST simulations have larger burden of $\mathrm{O}_{3}$ and $\mathrm{OH}$ than DUST_H simulations, and larger relative increases in $\mathrm{O}_{3}$ and $\mathrm{OH}$ are found in NO_DUST simulations when the additional $\mathrm{C}_{3} \mathrm{H}_{6}$ is considered, thus the effect of heterogeneous dust reactions (i.e. NO_DUST-DUST_H) are expanded, especially for $\mathrm{OH}$. This indicates that the qualitative results discussed above, especially for ozone, would likely be similar in a model which included a more detailed representation of the higher VOC, though there may be some interesting detailed differences, especially for $\mathrm{OH}$ due to the differences in reactivity of various VOCs, which might be interesting to investigate in the future. 
Table 8. Values of the uncertainties corresponding to Fig. 10. Columns are different heterogeneous removal reactions (HR) and rows are uncertainties in the tracer mixing ratios in percent $(\mathrm{Un}(\%))$.

\begin{tabular}{|c|c|c|c|c|c|c|c|c|c|c|c|c|}
\hline $\begin{array}{l}\text { HR } \\
\text { Un(\%) }\end{array}$ & $\mathrm{O}_{3}$ & $\mathrm{NO}_{2}$ & $\mathrm{NO}_{3}$ & $\mathrm{~N}_{2} \mathrm{O}_{5}$ & $\mathrm{HNO}_{3}$ & $\mathrm{OH}$ & $\mathrm{HO}_{2}$ & $\mathrm{H}_{2} \mathrm{O}_{2}$ & $\mathrm{HCHO}$ & $\mathrm{CH}_{3} \mathrm{OH}$ & $\mathrm{CH}_{3} \mathrm{COOH}$ & $\mathrm{SO}_{2}$ \\
\hline $\mathrm{SO}_{2}$ & -0.01 & -0.08 & 0.00 & 0.00 & 0.00 & 0.00 & 0.00 & 0.00 & 0.01 & 0.00 & 0.00 & -93.34 \\
\hline $\mathrm{CH}_{3} \mathrm{COOH}$ & 0.00 & 0.00 & 0.00 & 0.00 & 0.00 & 0.00 & 0.00 & 0.00 & 0.00 & 0.00 & -2.75 & 0.00 \\
\hline $\mathrm{CH}_{3} \mathrm{OH}$ & -0.05 & -0.21 & 0.00 & 0.00 & 0.00 & 0.01 & 0.01 & 0.00 & 0.03 & -64.28 & 0.00 & 0.00 \\
\hline $\mathrm{HCHO}$ & 3.16 & 23.15 & 0.00 & 0.03 & -0.03 & -0.61 & -0.84 & 0.00 & -92.16 & -0.13 & 0.00 & 0.17 \\
\hline $\mathrm{H}_{2} \mathrm{O}_{2}$ & -0.02 & 1.45 & 0.00 & 0.00 & 0.00 & -0.01 & 0.42 & -0.68 & -0.15 & 0.00 & 0.00 & -0.06 \\
\hline $\mathrm{HO}_{2}$ & -5.66 & 365.55 & 0.01 & 0.14 & -0.16 & -3.61 & -8.18 & -0.01 & -38.40 & -0.26 & -0.01 & -14.45 \\
\hline $\mathrm{OH}$ & 45.04 & 340.42 & 0.04 & 0.34 & -0.39 & -8.62 & -11.58 & -0.03 & -54.75 & -0.12 & 0.00 & 2.44 \\
\hline $\mathrm{HNO}_{3}$ & 0.00 & -0.01 & 0.00 & 0.00 & -46.60 & 0.00 & 0.00 & 0.00 & 0.00 & 0.00 & 0.00 & 0.00 \\
\hline $\mathrm{N}_{2} \mathrm{O}_{5}$ & -4.65 & -2.98 & -0.02 & -3.87 & 0.00 & -0.02 & -0.05 & 0.00 & -0.26 & 0.00 & 0.00 & -0.09 \\
\hline $\mathrm{NO}_{3}$ & -50.90 & -34.47 & -0.22 & -0.40 & -0.03 & -0.30 & -0.64 & 0.00 & -3.12 & -0.02 & 0.00 & -1.06 \\
\hline $\mathrm{NO}_{2}$ & -25.37 & -75.67 & -0.03 & -0.29 & -0.01 & -0.09 & -0.25 & 0.00 & -1.15 & -0.01 & 0.00 & -0.56 \\
\hline $\mathrm{O}_{3}$ & -49.17 & -48.08 & -0.04 & -0.23 & -0.02 & -0.29 & -0.63 & 0.00 & -3.11 & -0.02 & 0.00 & -1.04 \\
\hline
\end{tabular}

Table 9. Results from the sensitivity simulations with additional surrogate VOC emissions in the NO_DUST and DUST_H simulations. "S1" and "S2" represent the results of the simulations with $25 \%$ of total VOC (as C-atoms) emission distributed to C3H6 and C4H10, respectively. "S0" represents the results in Sect. 3.2. Listed in the table are the differences (calculated as S1-S0 and S2-S0) in O3 mixing ratio and OH concentration for the NO_DUST and DUST_H simulations, and the uncertainties in the dust heterogeneous influences. " $\Delta$ " means the dust heterogeneous influences calculated as DUST_H-NO_DUST; The relative differences (calculated as (S1-S0)/S0 and (S2-S0)/S0) are shown in parentheses.

\begin{tabular}{lllllll}
\hline Tracer & \multicolumn{2}{c}{$\begin{array}{c}\mathrm{O}_{3} \\
\mathrm{nmol} \mathrm{mol}^{-1} \\
\text { DUST_H }\end{array}$} & $\begin{array}{l}\Delta \mathrm{O}_{3} \\
\mathrm{nmol} \mathrm{mol}^{-1}\end{array}$ & & $\begin{array}{c}\text { OH molecules } \\
\mathrm{cm}^{-3}\end{array}$ & $\begin{array}{c}\Delta \mathrm{OH} \\
\mathrm{molecules} \mathrm{cm}^{-3}\end{array}$ \\
Simulation & NO_DUST & \multicolumn{2}{c}{ NO_DUST } & DUST_H & \\
Difference & & & & & \\
\hline S1-S0 & $0.78(8.3 \%)$ & $0.29(5.7 \%)$ & $-0.48(11.5 \%)$ & $3.5 \times 10^{4}(27.8 \%)$ & $2.6 \times 10^{4}(21.7 \%)$ & $-8.5 \times 10^{3}(192 \%)$ \\
S2-S0 & $-0.07(-0.7 \%)$ & $-0.03(-0.5 \%)$ & $0.04(-1 \%)$ & $-7.5 \times 10^{3}(-6.1 \%)$ & $-7.3 \times 10^{3}(-6.1 \%)$ & $2.6 \times 10^{2}(-5.8 \%)$ \\
\hline
\end{tabular}

\section{Summary and conclusions}

In this study, a box model is used in which detailed gas-phase chemistry is combined with dust surface uptake processes. Based on the output from a global atmospheric chemistry general circulation model and a regional emission inventory of North China, we design the "box" to represent the typical polluted condition in urban area of Beijing megacity. Dust is assumed to be transported together with other gas-phase species over the polluted region at various speeds. The influences of dust on tropospheric photochemistry via heterogeneous removal under different assumed transport speeds have been investigated and discussed in detail.

The influences due to mixing with upwind air mass have been discussed first, without considering the heterogeneous reactions on dust (i.e. NO_DUST simulations). It is found that the $\mathrm{O}_{\mathrm{x}}$ mixing ratio and $\mathrm{OH}$ concentration both increase while the $\mathrm{NO}_{\mathrm{x}}$ mixing ratio decreases with the increasing $K_{t}$ (consistent with upwind levels of $\mathrm{O}_{3}$ and $\mathrm{NO}_{\mathrm{x}}$ ). Similar tendencies of the $\mathrm{O}_{\mathrm{x}}$ and $\mathrm{NO}_{\mathrm{x}}$ mixing ratios are also found when the heterogeneous reactions are considered (i.e., in the DUST_H simulations), while the $\mathrm{OH}$ concentration is roughly constant in the simulations with the varying $K_{t}$.

The overall effect of introducing the heterogeneous dust reactions is to decrease the $\mathrm{O}_{\mathrm{x}}$ mixing ratio. The change ranges from -2.5 to $-18.4 \mathrm{nmol} \mathrm{mol}^{-1}$, and is larger for faster mixing in of upwind air masses (i.e. greater $K_{t}$ ). This translates into a large relative change in $\mathrm{O}_{\mathrm{x}}$, ranging from $-44 \%$ to $-55 \%$, which changes slightly with increasing values of $K_{t}$. This is comparable to the global results of Dentener et al. (1996), who found changes in the range of $-50 \%$ to $-20 \%$. The $\mathrm{NO}_{\mathrm{x}}$ mixing ratio is decreased due to introducing the heterogeneous dust reactions. The decrease ranges from -18 to $-2.7 \mathrm{nmol} \mathrm{mol}^{-1}$ (a relative decrease of $-8 \%$ to $-9 \%$ ), and is smaller for faster mixing in of upwind air masses (i.e. greater $K_{t}$ ). The influence on $\mathrm{OH}$ due to the heterogeneous dust reactions on dust is complex. The $\mathrm{OH}$ concentration is increased for smaller $K_{t}(4 \%$ in the T16 case), but decreased for greater $K_{t}$ (up to $-33 \%$ in the T02 case). It would be difficult to predict the anticipated change in $\mathrm{OH}$ for other cities without model simulations (box or 3D) applicable to their specific conditions. 
In the T04 case, by introducing an artificial 50\% decrease of all photolysis rate coefficients, we estimate that the relative contributions of the heterogeneous removal on dust and the decrease in photolytic rates to the decrease in $\mathrm{O}_{\mathrm{x}}$ mixing ratio are $87 \%$ (calculated by $\left(y_{(\mathrm{DUST} / \mathrm{H})}-\right.$ $\left.\left.y_{\text {(NO_DUST) }}\right) /\left(y_{(\text {DUST_H+J) }}-y_{\text {(NO_DUST) }}\right)\right)$ and $28 \%$ (calculated by $\left(y_{\text {(DUST_J })}-y_{\text {(NO_DUST })}\right) /\left(y_{\text {(DUST_H }+\mathrm{J})}-\right.$ $\left.y_{\text {(NO_DUST) }}\right)$ ), respectively (note that this is only an approximate relative apportionment, because combining the two processes in the DUST_H $+\mathrm{J}$ run might cause nonlinear effects, which could lead to a smaller influence on $\mathrm{O}_{\mathrm{x}}$ than the linearly summed influence, as discussed in Sect. 3.3, so that the sum of the two relative contributions is larger than 100\%). They approximately fit to the values reported by Zhang et al. (1999) which are $79.7 \%-92.9 \%$ and $7.1 \%-20.3 \%$, respectively.

It should be noted that in reality there is a dependence of the dust source on the wind speed (normally faster winds cause larger upwind sources), so the approach of assuming a constant upwind dust mixing ratio and size distribution for all four exchange rate coefficient cases will tend to underestimate the spread in the effects from T16 to T02.

The potential uncertainties due to different uptake coefficients are investigated in the T08 case. It is found that for most of the gases which are heterogeneously removed, the self-removal results in the largest uncertainty (with the important exceptions of $\mathrm{OH}$ and $\mathrm{HO}_{2}$ ). The heterogeneous removal of $\mathrm{NO}_{2}$ is particularly important due to its influence on the uncertainties in $\mathrm{OH}$ and $\mathrm{HO}_{2}$; the heterogeneous removal of $\mathrm{HCHO}$ and $\mathrm{O}_{3}$ also have similar farther-reaching effects. The results clearly indicate that the uncertainty in the uptake coefficients result in large uncertainties for the influence of dust under polluted conditions, and suggest that further laboratory work, especially on the uptake of $\mathrm{NO}_{2}, \mathrm{HCHO}$ and $\mathrm{O}_{3}$, will be valuable for reducing the uncertainties in future modeling studies.

This paper provides an analysis of potential influences of dust under the conditions of a typical highly polluted region. For global atmospheric chemistry and climate change studies, the overall $\mathrm{O}_{3}$ change in the column due to dust is important. In a 3-D model study, Bian and Zender (2003) reported that in the real atmosphere the sensitivity of $\mathrm{O}_{3}$ to the vertical location of dust is complicated and can change signs depending on the presence of $\mathrm{O}_{3}$ precursors. Given this complexity, the overall influence of dust over the column will be examined in a follow-up 3-D model study. This study will provide guidance for the incorporation and analysis of heterogeneous dust reactions in a regional 3-D chemistry-transport model, which is being developed to study the impacts of dust on tropospheric photochemistry in different polluted areas of North China. Considering the large uncertainties demonstrated in this study, we will place particular emphasis on using sensitivity studies to evaluate the uptake coefficients appropriate for North China.

\section{Appendix A}

\section{Review of the heterogeneous uptake coefficient values measured and adopted in former laboratory and model studies}

\section{$\begin{array}{lll}\mathrm{A} 1 & \mathrm{O}_{3}\end{array}$}

Many direct measurements of $\mathrm{O}_{3}$ uptake on mineral dust were recently performed with contradictory results (Michel et al., 2002, 2003; Hanisch and Crowley, 2003; Usher et al., 2003). Values of $\gamma$ in the range of approximately $10^{-6} \sim 10^{-4}$ were reported. In recent model studies, $1 \times 10^{-5}$ was used by Liao et al. (2004), Liao and Seinfeld (2005), Tie et al. (2005), Bauer et al. (2004), and Pozzoli et al. (2008). In this study, the value $2.7 \times 10^{-5}$ recommended by The International Union of Pure and Applied Chemistry (IUPAC) for China loess is used (http://www.iupac-kinetic.ch.cam.ac.uk).

\section{A2 $\mathrm{HNO}_{3}, \mathrm{~N}_{2} \mathrm{O}_{5}, \mathrm{NO}_{3}$ and $\mathrm{NO}_{2}$}

The reaction of nitric acid with mineral dust aerosols has been recently addressed by several laboratory studies (Hanisch and Crowley, 2001; Goodman et al., 2000; Underwood et al., 2001; Grassian, 2002). This reaction irreversibly removes $\mathrm{HNO}_{3}$ from the gas phase. The reported $\gamma$ for $\mathrm{HNO}_{3}$ varies from approximately $10^{-5}$ to 0.2 . In model studies, $10^{-3}$ was used by Bian and Zender (2003), while 0.1 was used by Liao et al. (2004), Liao and Seinfeld (2005), Tie et al. (2005), Pozzoli et al. (2008), Dentener et al. (1996), and Bauer et al. (2004). A larger value of 0.17 recommended by IUPAC for Chinese dust is adopted for this study.

In recent laboratory work, the uptake of $\mathrm{N}_{2} \mathrm{O}_{5}$ on mineral dust was investigated by Seisel et al. (2005), Karagulian et al. (2006) and Wagner et al. (2008). Seisel et al. (2005) and Wagner et al. (2008) reported similar values of about $10^{-2}$, while Karagulian et al. (2006) reported significantly larger values (about $10^{-1}$ ). In model studies, Dentener et al. (1996), Bian and Zender (2003) used the value 0.1, while values between 0.003 and 0.02 depending on the relative humidity were used by Bauer et al. (2004), Liao et al. (2004), Liao and Seinfeld (2005), and Pozzoli et al. (2008). The value 0.03 is chosen as a compromise for this study.

Some experiments focusing directly on the uptake of $\mathrm{NO}_{3}$ on mineral dust surfaces have been performed by Karagulian and Rossi (2005). The measured uptake coefficient ranged from roughly 0.01 to 0.23 for different mineral dusts. Tang et al. (2010) determined that $\gamma\left(\mathrm{NO}_{3}\right) / \gamma\left(\mathrm{N}_{2} \mathrm{O}_{5}\right)=0.9 \pm 0.4$ for Saharan dust, indicating an uptake coefficient of $\gamma\left(\mathrm{NO}_{3}\right)=$ $9 \times 10^{-3}$ with an associated uncertainty of at least factor of two. These values are significantly larger than the $\gamma$ value of $3.0 \times 10^{-3}$ for $\mathrm{NO}_{3}$ used by Bauer et al. (2004). An intermediate $\gamma$ value of 0.1 for $\mathrm{NO}_{3}$ was used for the modeling studies performed by Bian and Zender (2003) and Pozzoli et al. (2008), and is also used in this study. 
The initial uptake coefficients for $\mathrm{NO}_{2}$ on the surface of different mineral particles were measured by Underwood et al. (2001). The $\gamma$ value ranges from $<4 \times 10^{-10}$ to $2 \times 10^{-5}$, with most values in the $10^{-6}$ range. Ullerstam et al. (2003) measured the uptake coefficient of $\mathrm{NO}_{2}$ for Saharan dust. They reported the uptake coefficient as $(2.0 \pm 0.4) \times 10^{-4}$ for geometric area. IUPAC recommends an upper limit of $1 \times 10^{-6}$ for $\gamma$, considering that it will be smaller as the dust aging (e.g. being coated with nitrate from $\mathrm{HNO}_{3}$ uptake). The modeling study performed by Bian and Zender (2003) used a $\gamma$ value of $4.4 \times 10^{-5}$ for $\mathrm{NO}_{2}$. In this study, we employ a lower value of $2.1 \times 10^{-6}$ recommended by IUPAC for China loess.

\section{$\mathrm{A3} \mathrm{HO}_{2}, \mathrm{OH}$ and $\mathrm{H}_{2} \mathrm{O}_{2}$}

Laboratory experiments on the uptake of $\mathrm{OH}$ and $\mathrm{HO}_{2}$ on sulfuric acid and water surfaces show reactive uptake coefficients which range from 0.004 to 1 for $\mathrm{OH}$, and from 0.01 to 1 for $\mathrm{HO}_{2}$ (Hanson et al., 1992). Unfortunately no laboratory studies of the uptake of the $\mathrm{HO}_{2}$ radical on mineral dust aerosol are documented; however, in a review, Jacob (2000) recommends including the uptake of $\mathrm{HO}_{2}$ by aerosols with $\gamma=0.2$ in atmospheric chemistry models, and also concludes that although the mechanism for $\mathrm{HO}_{2}$ uptake is uncertain, $\mathrm{H}_{2} \mathrm{O}_{2}$ is the likely product. Here we adopt this recommendation for $\gamma$, as well as the assumption that $\mathrm{H}_{2} \mathrm{O}_{2}$ is the only reaction product with a $100 \%$ yield. For the uptake coefficient of $\mathrm{OH}$, we adopt the value of 0.1 , based on DeMore et al. (1997). This value was also used by Bian and Zender (2003) and Zhang and Carmichael (1999) in their modeling studies of the heterogeneous chemistry on mineral dust.

Measured mass accommodation coefficients of $\mathrm{H}_{2} \mathrm{O}_{2}$ on sulfuric acid and water surfaces, within a range from $8 \times 10^{-4}$ to 0.18, are reported by DeMore et al. (1997). In the modeling studies of Dentener et al. (1996), Bian and Zender (2003) and Zhang and Carmichael (1999), $\gamma=1.0 \times 10^{-4}$ was used for mineral dust surfaces. However, de Reus et al. (2005), employing the assumption that $\mathrm{H}_{2} \mathrm{O}_{2}$ is formed when $\mathrm{HO}_{2}$ is taken up in the Saharan dust aerosol, concluded that the heterogeneous removal of $\mathrm{HO}_{2}$ and $\mathrm{H}_{2} \mathrm{O}_{2}$, with accommodation coefficients of 0.2 and $2 \times 10^{-3}$, respectively, had to be included in order to obtain agreement between calculated and observed values. In this study, we use the values from de Reus et al. (2005).

\section{A4 Acetic acid, formaldehyde and methanol}

The heterogeneous uptake of VOC (volatile organic compound) has rarely been included in modeling studies. In this study, in order to explore the potential sensitivity to these reactions, we use uptake coefficients for acetic acid $\left(\mathrm{CH}_{3} \mathrm{COOH}\right)$, formaldehyde $(\mathrm{HCHO})$, and methanol $\left(\mathrm{CH}_{3} \mathrm{OH}\right)$ of $10^{-3}, 10^{-5}$ and $10^{-5}$, respectively, based on the laboratory measurements performed by Carlos-Cuellar et al. (2003).

\section{A5 $\quad \mathrm{SO}_{2}$}

Recently, the heterogeneous reactivity of $\mathrm{SO}_{2}$ has been studied on metal oxides (Goodman et al., 2001; Usher et al., 2002), China Loess dust (Usher et al., 2002) and Saharan mineral dust (Ullerstam et al., 2002; Ullerstam et al., 2003; Adams et al., 2005). The reported $\gamma$ values range from roughly $5 \times 10^{-7}$ to $2.6 \times 10^{-4}$. Pozzoli et al. (2008) used a value of $1 \times 10^{-4}$ in their modeling study. The value of $3 \times 10^{-5}$ recommended by IUPAC for Chinese dust has been used in this study.

\section{Appendix B}

\section{Formula derivation for Eq. (B4)}

Based on Eq. (B1):

$$
C_{i}=\frac{K_{t} \cdot C_{i}^{\prime}+B_{e}+B_{c p}}{K_{t}+K_{c l}+K_{d}},
$$

the heterogeneous influence on the tracer daily average concentration is represented as (for any species $i$, leaving out the subscript here for readability):

$$
\begin{aligned}
& \Delta C=C_{(\text {DUST_H })}-C_{(\text {NO_DUST })} \\
& =\frac{K_{t} \cdot C^{\prime}+B_{e}+B_{c p \text { (DUST_H) }}}{K_{t}+K_{c l \text { (DUST_H })}+K_{d}}-\frac{K_{t} \cdot C^{\prime}+B_{e}+B_{c p \text { (NO_DUST) }}}{K_{t}+K_{c l \text { (NO_DUST) }}+K_{d}} \\
& =\frac{\left(K_{c l \text { (NO_DUST) }}-K_{c l \text { (DUST_H })}\right) \cdot\left(K_{t} \cdot C^{\prime}+B_{e}+B_{c p \text { (NO_DUST) }}\right)}{\left(K_{t}+K_{c l \text { (NO_DUST })}+K_{d}\right) \cdot\left(K_{t}+K_{c l(\text { DUST_H })}+K_{d}\right)} \\
& +\frac{\left.\left(B_{c p} \text { (DUST_H }\right)-B_{c p \text { (NO_DUST) }}\right) \cdot\left(K_{t}+K_{c l \text { (NO_DUST) }}+K_{d}\right)}{\left(K_{t}+K_{c l \text { (NO_DUST })}+K_{d}\right) \cdot\left(K_{t}+K_{c l \text { (DUST_H })}+K_{d}\right)}
\end{aligned}
$$

where $\Delta C$ is the difference in the tracer daily average concentration between the NO_DUST and DUST_H simulations (DUST_H-NO_DUST). Recognizing that

$$
\frac{\left(K_{t} \cdot C^{\prime}+B_{e}+B_{c p(\text { NO_DUST })}\right)}{\left(K_{t}+K_{c l(\text { NO_DUST })}+K_{d}\right)}=C_{(\text {NO_DUST })},
$$

and defining $K_{c l \text { (NO_DUST) }}-K_{c l \text { (DUST_H })}=-\Delta K_{c l}$ and $B_{c p(\text { DUST_H })}-B_{c p \text { (NO_DUST })}=\Delta B_{c p}$, we can simplify the formula to:

$\Delta C=\frac{\Delta B_{c p}-\Delta K_{c l} \cdot C_{(\text {NO_DUST })}}{\left(K_{t}+K_{c l(\text { DUST_H })}+K_{d}\right)}$. 


\section{Appendix C}

Table C1. The absolute differences in the tracer mixing ratios calculated with the "Upper Limit" and "Lower Limit" coefficients $\left(y_{\text {DUST_H }}\left(\gamma_{\text {Upper }}\right)-y_{\text {DUST_H }}\left(\gamma_{\text {Lower }}\right)\right)$. Columns are different heterogeneous removal reactions $(\mathrm{HR})$ and rows are absolute differences in $\operatorname{ppbv}\left(\mathrm{AD}\left(\mathrm{nmol} \mathrm{mol}{ }^{-1}\right)\right)$.

\begin{tabular}{|c|c|c|c|c|c|c|c|c|c|c|c|c|}
\hline $\begin{array}{l}\mathrm{HR} \\
\mathrm{AD} \\
(\mathrm{nmol} \mathrm{mol}-1)\end{array}$ & $\mathrm{O}_{3}$ & $\mathrm{NO}_{2}$ & $\mathrm{NO}_{3}$ & $\mathrm{~N}_{2} \mathrm{O}_{5}$ & $\mathrm{HNO}_{3}$ & $\mathrm{OH}$ & $\mathrm{HO}_{2}$ & $\mathrm{H}_{2} \mathrm{O}_{2}$ & $\mathrm{HCHO}$ & $\mathrm{CH}_{3} \mathrm{OH}$ & $\mathrm{CH}_{3} \mathrm{COOH}$ & $\mathrm{SO}_{2}$ \\
\hline $\mathrm{SO}_{2}$ & $-3.9 \mathrm{E}-02$ & $-2.9 \mathrm{E}-01$ & $-6.1 \mathrm{E}-05$ & $-3.1 \mathrm{E}-04$ & $3.5 \mathrm{E}-04$ & $7.5 \mathrm{E}-03$ & $1.0 \mathrm{E}-02$ & $6.1 \mathrm{E}-05$ & $4.7 \mathrm{E}-02$ & $1.2 \mathrm{E}-04$ & $3.1 \mathrm{E}-05$ & $-3.2 \mathrm{E}+02$ \\
\hline $\mathrm{CH}_{3} \mathrm{COOH}$ & $2.4 \mathrm{E}-07$ & $-2.9 \mathrm{E}-05$ & $0.0 \mathrm{E}+00$ & $-2.6 \mathrm{E}-06$ & $-6.9 \mathrm{E}-06$ & $-1.4 \mathrm{E}-06$ & $-6.3 \mathrm{E}-05$ & $-1.5 \mathrm{E}-05$ & 2.7E-05 & $0.0 \mathrm{E}+00$ & $-9.0 \mathrm{E}-02$ & 4.1E-06 \\
\hline $\mathrm{CH}_{3} \mathrm{OH}$ & $-2.6 \mathrm{E}-03$ & $-1.2 \mathrm{E}-02$ & $-2.1 \mathrm{E}-06$ & $-1.7 \mathrm{E}-05$ & $1.3 \mathrm{E}-05$ & $3.0 \mathrm{E}-04$ & $4.0 \mathrm{E}-04$ & $1.7 \mathrm{E}-06$ & $1.9 \mathrm{E}-03$ & $-3.7 \mathrm{E}+00$ & $4.8 \mathrm{E}-07$ & $-1.1 \mathrm{E}-04$ \\
\hline $\mathrm{HCHO}$ & 7.9E-02 & $5.8 \mathrm{E}-01$ & 7.5E-05 & $6.4 \mathrm{E}-04$ & $-6.7 \mathrm{E}-04$ & $-1.5 \mathrm{E}-02$ & $-2.1 \mathrm{E}-02$ & $-6.4 \mathrm{E}-05$ & $-2.3 \mathrm{E}+00$ & $-3.2 \mathrm{E}-03$ & $-1.1 \mathrm{E}-04$ & $4.3 \mathrm{E}-03$ \\
\hline $\mathrm{H}_{2} \mathrm{O}_{2}$ & $-4.3 \mathrm{E}-05$ & $2.8 \mathrm{E}-03$ & $1.0 \mathrm{E}-07$ & $1.1 \mathrm{E}-06$ & $-1.2 \mathrm{E}-06$ & $-2.8 \mathrm{E}-05$ & $8.0 \mathrm{E}-04$ & $-1.3 \mathrm{E}-03$ & $-3.0 \mathrm{E}-04$ & $-2.0 \mathrm{E}-06$ & $2.4 \mathrm{E}-07$ & $-1.1 \mathrm{E}-04$ \\
\hline $\mathrm{HO}_{2}$ & & & & & & & & & $-6.3 \mathrm{E}-06$ & $-4.2 \mathrm{E}-08$ & $-1.2 \mathrm{I}$ & $-2.4 \mathrm{E}-06$ \\
\hline $\mathrm{OH}$ & $2.3 \mathrm{E}-06$ & $1.8 \mathrm{E}-05$ & 2.3E-09 & $1.8 \mathrm{E}-08$ & $-2.0 \mathrm{E}-08$ & $-4.5 \mathrm{E}-07$ & $-6.0 \mathrm{E}-07$ & $-1.5 \mathrm{E}-09$ & $-2.8 \mathrm{E}-06$ & $-6.5 \mathrm{E}-09$ & $-2.1 \mathrm{E}-10$ & $1.3 \mathrm{E}-07$ \\
\hline $\mathrm{HNO}_{3}$ & $-3.3 \mathrm{E}-05$ & $-1.3 \mathrm{E}-04$ & $0.0 \mathrm{E}+00$ & $-2.4 \mathrm{E}-07$ & $-1.2 \mathrm{E}+00$ & $-1.9 \mathrm{E}-05$ & $-2.6 \mathrm{E}-05$ & $0.0 \mathrm{E}+00$ & $-1.2 \mathrm{E}-04$ & $-2.4 \mathrm{E}-07$ & $0.0 \mathrm{E}+00$ & $2.9 \mathrm{E}-06$ \\
\hline $\mathrm{N}_{2} \mathrm{O}_{5}$ & $-1.0 \mathrm{E}-04$ & $-6.4 \mathrm{E}-05$ & $-3.6 \mathrm{E}-07$ & $-8.3 \mathrm{E}-05$ & $-5.1 \mathrm{E}-08$ & $-5.0 \mathrm{E}-07$ & $-1.1 \mathrm{E}-06$ & $-2.3 \mathrm{E}-09$ & $-5.5 \mathrm{E}-06$ & $-3.5 \mathrm{E}-08$ & $-2.6 \mathrm{E}-09$ & $-2.0 \mathrm{E}-06$ \\
\hline $\mathrm{NO}_{3}$ & $-4.1 \mathrm{E}-06$ & $-2.8 \mathrm{E}-06$ & $-1.8 \mathrm{E}-08$ & $-3.3 \mathrm{E}-08$ & $-2.3 \mathrm{E}-09$ & $-2.4 \mathrm{E}-08$ & $-5.2 \mathrm{E}-08$ & $-1.1 \mathrm{E}-10$ & $-2.5 \mathrm{E}-07$ & $-1.5 \mathrm{E}-09$ & $-1.0 \mathrm{E}-10$ & $-8.6 \mathrm{E}-08$ \\
\hline $\mathrm{NO}_{2}$ & $-1.8 \mathrm{E}+01$ & $-5.3 \mathrm{E}+01$ & $-1.9 \mathrm{E}-02$ & $-2.0 \mathrm{E}-01$ & $-8.2 \mathrm{E}-03$ & $-6.6 \mathrm{E}-02$ & $-1.8 \mathrm{E}-01$ & $-3.1 \mathrm{E}-04$ & $-8.1 \mathrm{E}-01$ & $-6.6 \mathrm{E}-03$ & $-3.8 \mathrm{E}-04$ & $-4.0 \mathrm{E}-01$ \\
\hline $\mathrm{O}_{3}$ & $-4.5 \mathrm{E}+00$ & $-4.4 \mathrm{E}+00$ & $-3.3 \mathrm{E}-03$ & $-2.1 \mathrm{E}-02$ & $-1.8 \mathrm{E}-03$ & $-2.7 \mathrm{E}-02$ & $-5.8 \mathrm{E}-02$ & $-1.2 \mathrm{E}-04$ & $-2.9 \mathrm{E}-01$ & $-1.7 \mathrm{E}-03$ & $-9.9 \mathrm{E}-05$ & $-9.6 \mathrm{E}-02$ \\
\hline
\end{tabular}

\section{Appendix D}

Table D1. The uncertainties computed by normalizing the absolute differences by the tracer mixing ratios calculated with the "Best Guess" coefficients. Columns are different heterogeneous removal reactions (HR) and rows are uncertainties in percent (Un(\%)).

\begin{tabular}{|c|c|c|c|c|c|c|c|c|c|c|c|c|}
\hline $\begin{array}{l}\text { HR } \\
\text { Un(\%) }\end{array}$ & $\mathrm{O}_{3}$ & $\mathrm{NO}_{2}$ & $\mathrm{NO}_{3}$ & $\mathrm{~N}_{2} \mathrm{O}_{5}$ & $\mathrm{HNO}_{3}$ & $\mathrm{OH}$ & $\mathrm{HO}_{2}$ & $\mathrm{H}_{2} \mathrm{O}_{2}$ & $\mathrm{HCHO}$ & $\mathrm{CH}_{3} \mathrm{OH}$ & $\mathrm{CH}_{3} \mathrm{COOH}$ & $\mathrm{SO}_{2}$ \\
\hline $\mathrm{SO}_{2}$ & -0.04 & -0.31 & 0.00 & 0.00 & 0.00 & 0.01 & 0.01 & 0.00 & 0.05 & 0.00 & 0.00 & -339.96 \\
\hline $\mathrm{CH}_{3} \mathrm{COOH}$ & 0.01 & -0.93 & 0.00 & -0.09 & -0.23 & -0.05 & -2.04 & -0.49 & 0.89 & 0.00 & -2921.05 & 0.13 \\
\hline $\mathrm{CH}_{3} \mathrm{OH}$ & -0.10 & -0.48 & 0.00 & 0.00 & 0.00 & 0.01 & 0.02 & 0.00 & 0.07 & -145.72 & 0.00 & 0.00 \\
\hline HCHO & 5.83 & 42.71 & 0.01 & 0.05 & -0.05 & -1.13 & -1.54 & 0.00 & -170.00 & -0.24 & -0.01 & 0.32 \\
\hline $\mathrm{H}_{2} \mathrm{O}_{2}$ & -9.32 & 597.80 & 0.02 & 0.24 & -0.26 & -5.99 & 172.04 & -279.25 & -63.52 & -0.42 & 0.05 & -23.92 \\
\hline $\mathrm{HO}_{2}$ & -9.42 & 607.82 & 0.02 & 0.24 & -0.26 & -6.01 & -13.60 & -0.02 & -63.85 & -0.43 & -0.01 & -24.03 \\
\hline $\mathrm{OH}$ & 46.69 & 352.89 & 0.05 & 0.35 & -0.40 & -8.94 & -12.01 & -0.03 & -56.75 & -0.13 & 0.00 & 2.53 \\
\hline $\mathrm{HNO}_{3}$ & -16.05 & -60.74 & 0.00 & -0.12 & -558522.12 & -9.01 & -12.47 & 0.00 & -57.73 & -0.12 & 0.00 & 1.39 \\
\hline $\mathrm{N}_{2} \mathrm{O}_{5}$ & -222.03 & -142.35 & -0.80 & -184.60 & -0.11 & -1.11 & -2.53 & -0.01 & -12.26 & -0.08 & -0.01 & -4.51 \\
\hline $\mathrm{NO}_{3}$ & -172.81 & -117.02 & -0.74 & -1.37 & -0.10 & -1.00 & -2.17 & 0.00 & -10.59 & -0.06 & 0.00 & -3.59 \\
\hline $\mathrm{NO}_{2}$ & -36.77 & -109.69 & -0.04 & -0.42 & -0.02 & -0.14 & -0.37 & 0.00 & -1.67 & -0.01 & 0.00 & -0.81 \\
\hline $\mathrm{O}_{3}$ & -89.76 & -87.78 & -0.07 & -0.42 & -0.04 & -0.53 & -1.15 & 0.00 & -5.68 & -0.03 & 0.00 & -1.90 \\
\hline
\end{tabular}

Acknowledgements. This work was supported by NSFC (grant no. 40775073 and 40433008) and IMPRS. We would like to thank Wei Wang for providing the aircraft measurement data and Benedikt Steil for providing the EMAC simulation results. Also thanks to the MESSy Team for their assistance with the model. We appreciate helpful comments on the manuscript from John Crowley and Eva Bauer.

The service charges for this open access publication have been covered by the Max Planck Society.

Edited by: A. Hofzumahaus

\section{References}

Adams, J. W., Rodriguez, D., and Cox, R. A.: The uptake of $\mathrm{SO}_{2}$ on Saharan dust: a flow tube study, Atmos. Chem. Phys., 5, 2679-
2689, 2005,

http://www.atmos-chem-phys.net/5/2679/2005/.

Bauer, S. E., Balkanski, Y., Schulz, M., and Haughlustaine, D. A.: Global modeling of heterogeneous chemistry on mineral aerosol surfaces: Influence on tropospheric ozone chemistry and comparison to observations, J. Geophys. Res., 109, D02304, doi:10.1029/2003JD003868, 2004.

Bian, H. and Zender, C. S.: Mineral dust and global tropospheric chemistry: Relative roles of photolysis and heterogeneous uptake, J. Geophys. Res., 108, 4672, doi:10.1029/2002JD003143, 2003.

Carlos-Cuellar, S., Li, P., Christensen, A. P., Krueger, B. J., Burrichter, C., and Grassian, V. H.: Heterogeneous Uptake Kinetics of Volatile Organic Compounds on Oxide Surfaces Using a Knudsen Cell Reactor: Adsorption of Acetic Acid, Formaldehyde, and Methanol on $\alpha-\mathrm{Fe}_{2} \mathrm{O}_{3}, \alpha-\mathrm{Al}_{2} \mathrm{O}_{3}$, and $\mathrm{SiO}_{2}$, J. Phys. Chem. A, 107, 4250-4261, 2003.

Crutzen, P. J. and U. Schmailzl: Chemical budgets of the strato- 
sphere, Planet. Space. Sci., 31, 1009-1032, 1983.

Dentener, F. J., Carmichael, G. R., Zhang, Y., Lelieveld, J., and Crutzen, P. J.: Role of mineral aerosol as a reactive surface in the global troposphere, J. Geophys. Res., 101, 22869-22889, 1996.

de Reus, M., Dentener, F., Thomas, A., Borrmann, S., Ström, J., and Lelieveld, J.: Airborne observations of dust aerosol over the North Atlantic Ocean during ACE-2: indications for heterogeneous ozone destruction, J. Geophys. Res., 105, 15263-15275, 2000.

de Reus, M., Fischer, H., Sander, R., Gros, V., Kormann, R., Salisbury, G., Van Dingenen, R., Williams, J., Zöllner, M., and Lelieveld, J.: Observations and model calculations of trace gas scavenging in a dense Saharan dust plume during MINATROC, Atmos. Chem. Phys., 5, 1787-1803, 2005,

http://www.atmos-chem-phys.net/5/1787/2005/.

DeMore, W. B., Sander, S. P., Golden, D. M., Hampson, R. F., Kurylo, M. J., Howard, C. J., Ravishankara, A. R., Kolb, C. E., and Molina, M. J.: Chemical kinetics and photochemical data for use in stratospheric modeling, National Aeronautics and Space Administration and Jet Propulsion Laboratory, California Institute of Technology, California, 1997.

Fuchs, N. A. and Sutugin, A. G.: Highly Dispersed Aerosols, Butterworth-Heinemann, Woburn, Mass., 1970.

Grassian, V. H.: Chemical Reactions of Nitrogen Oxides on the Surface of Oxide, Carbonate, Soot, and Mineral Dust Particles: Implications for the Chemical Balance of the Troposphere, J. Phys. Chem. A, 106, 860-877, 2002.

Gurjar, B. R., Butler, T., Lawrence, M. G., and Lelieveld, J.: Evaluation of emissions and air quality in megacities, Atmospheric Environment, 42, 1593-1606, 2008.

Goodman, A. L., Li, P., Usher, C. R., and Grassian, V. H.: Heterogeneous uptake of sulfur dioxide on aluminum and magnesium oxide particles, J. Phys. Chem. A, 105, 6109-6120, 2001.

Goodman, A. L., Underwood, G. M., and Grassian, V. H.: A laboratory study of the heterogeneous reaction of nitric acid on calcium carbonate particles, J. Geophys. Res., 105, 29053-29064, 2000.

Gong, S. L., Zhang, X. Y., Zhao, T. L., Zhang, X., McKendry, I. G., and Zhao, C. S.: A Simulated Climatology of Asian Dust Aerosol and its Trans-Pacific Transport 2. Interannual Variability and Climate Connections, J. Climate, 19, 104-122, 2006.

Hanson, D. R., Burkholder, J. B., Howard, C. J., and Ravishankara, A. R.: Measurements of $\mathrm{OH}$ and $\mathrm{HO}_{2}$ radical uptake coefficients on water and sulfuric acid surfaces, J. Phys. Chem., 96, 49794985, 1992.

Hanish, F. and Crowley, J. N.: Heterogeneous reactivity of gaseous nitric acid on $\mathrm{Al}_{2} \mathrm{O}_{3}, \mathrm{CaCO}_{3}$, and atmospheric dust samples: $\mathrm{A}$ Knudsen cell study, J. Phys. Chem. A, 105, 3096-3106, 2001.

Hanisch, F. and Crowley, J. N.: Ozone decomposition on Saharan dust: an experimental investigation, Atmos. Chem. Phys., 3, 119-130, 2003, http://www.atmos-chem-phys.net/3/119/2003/.

Haywood J., Francis, P., Osborne, S., Glew, M., Loeb, N., Highwood, E., Tanré, D., Myhre, G., Formenti, P., and Hirst, E.: Radiative properties and direct radiative effect of Saharan dust measured by the C-130 aircraft during SHADE: 1 . Solar spectrum, J. Geophys. Res., 108, 8577, doi:10.1029/2002JD002687, 2003.

Highwood E. J., Haywood, J. M., Silverstone, M. D., Newman, S. M., and Taylor, J. P.: Radiative properties and direct effect of Saharan dust measured by the C-130 aircraft during Saharan Dust
Experiment (SHADE): 2. Terrestrial spectrum, J. Geophys. Res., 108, 8578, doi:10.1029/2002JD002552, 2003.

Heikes, B. G. and Thompson, A. M.: Effects of heterogeneous processes on $\mathrm{NO}_{3}, \mathrm{HONO}$ and $\mathrm{HNO}_{3}$ chemistry in the troposphere, J. Geophys. Res., 88, 10883-10895, 1983.

IPCC (Intergovernmental Panel on Climate Change): Climate change 2007, The Physical Science Basis. Contribution of Working Group I to the Fourth Assessment Report of the Intergovernmental Panel on Climate Change, Cambridge University Press, Cambridge, UK and New York, NY, USA. 153 pp., 2007.

Jacob, D. J.: Heterogeneous chemistry and tropospheric ozone, Atmos. Environ., 34, 2131-2159, 2000.

Jeong, G.-R. and Sokolik, I. N.: Effect of mineral dust aerosols on the photolysis rates in the clean and polluted marine environments, J. Geophys. Res., 112, D21308, doi:10.1029/2007JD008442, 2007.

Jöckel, P., Tost, H., Pozzer, A., Brhl, C., Buchholz, J., Ganzeveld, L., Hoor, P., Kerkweg, A., Lawrence, M. G., Sander, R., Steil, B., Stiller, G., Tanarhte, M., Taraborrelli, D., van Aardenne, J., and Lelieveld, J.: The atmospheric chemistry general circulation model ECHAM5/MESSy 1: consistent simulation of ozone from the surface to the mesosphere, Atmos. Chem. Phys., 6, 50675104, 2006, http://www.atmos-chem-phys.net/6/5067/2006/.

Jickells, T. D., An, Z. S., Andersen , K. K., Baker, A. R., Bergametti, G., Brooks, N., Cao, J. J., Boyd, P. W., Duce, R. A., Hunter, K. A., Kawahata, H., Kubilay, N., laRoche, J., Liss, P. S., Mahowald, N., Prospero, J. M., Ridgwell, A. J., Tegen, I., and Torres, R.: Global iron connections between desert dust, ocean biogeochemistry and climate, Science, 308, 67-71, 2005.

Karagulian, F. and Rossi, M.: The heterogeneous chemical kinetics of $\mathrm{NO}_{3}$ on atmospheric mineral dust surrogates, Phys. Chem. Chem. Phys., 7, 3150-3162, 2005.

Karagulian, F., Santschi, C., and Rossi, M. J.: The heterogeneous chemical kinetics of $\mathrm{N}_{2} \mathrm{O}_{5}$ on $\mathrm{CaCO}_{3}$ and other atmospheric mineral dust surrogates, Atmos. Chem. Phys., 6, 1373-1388, 2006, http://www.atmos-chem-phys.net/6/1373/2006/.

Kaufman, Y. J., Tanré, D., and Boucher, O.: A satellite view of aerosols in the climate system, Nature, 419, 215-223, 2002.

Kleinman, L., Yin, N. L., Springston, S. R., Nunnermacker, L., Zhou, X., Brown, R., Hallock, K., Klotz, P., Leahy, D., Lee, J. H., and Newman, L.: Ozone formation at a rural site in the southeastern United States. J. Geophys. Res., 99, 3469-3482, 1994.

Kleinman, L. I.: Ozone process insights from field experiments, II, Observation-based analysis for ozone production. Atmos. Environ., 34, 2023-2033, 2000.

Lee, S. S., Chun, Y. S., Nam, J. C., Park, S. U., and Lee, E. H.: Estimation of dry deposition during Asian dust events in spring of 2002, J. Meteorol. Soc. Jpn., 38A, 241-254, 2005.

Liao, H., Seinfeld, J. H., Adams, P. J., and Mickley, L. J.: Global radiative forcing of coupled tropospheric ozone and aerosols in a unified general circulation model, J. Geophys. Res., 109, D16207, doi:10.1029/2003JD004456, 2004.

Liao, H. and Seinfeld, J. H.: Global impacts of gas-phase chemistryaerosol interactions on direct radiative forcing by anthropogenic aerosols and ozone, J. Geophys. Res., 110, D18208, doi:10.1029/2005JD005907, 2005.

Maher, B. A., Mutch, T. J., and Cunningham, D.: Magnetic and 
geochemical characteristics of Gobi Desert surface sediments: Implications for provenance of the Chinese Loess Plateau, Geology, 37, 279-282, 2009.

Michel, A. E., Usher, C. R., and Grassian, V. H., Heterogeneous and catalytic uptake of ozone on mineral oxides and dusts: A Knudsen cell investigation, Geophys. Res. Lett., 29, 1665, doi:10.1029/2002GL014896, 2002.

Michel, A. E., Usher, C. R., and Grassian, V. H.: Reactive uptake of ozone on mineral oxides and mineral dusts, Atmos. Environ., 37, 3201-3211, 2003.

Pozzoli, L., Bey, I., Rast, S., Schultz, M. G., Stier, P., and Feichter, J.: Trace gas and aerosol interactions in the fully coupled model of aerosol-chemistry-climate ECHAM5HAMMOZ: 1. Model description and insights from the spring 2001 TRACE-P experiment, J. Geophys. Res., 113, D07308, doi:10.1029/2007JD009007, 2008.

Reddy M. S., Boucher, O., Balkanski, Y., and Schulz, M.: Aerosol optical depths and direct radiative perturbations by species and source type, Geophys. Res. Lett., 32, L12803, doi:10.1029/2004GL021743, 2005.

Sander, R., Kerkweg, A., Jöckel, P., and Lelieveld, J.: Technical note: The new comprehensive atmospheric chemistry module MECCA, Atmos. Chem. Phys., 5, 445-450, 2005, http://www.atmos-chem-phys.net/5/445/2005/.

Sander, S. P., Finlayson-Pitts, B. J., Friedl, R. R., Golden, D. M., Huie, R. E., Kolb, C. E., Kurylo, M. J., Molina, M. J., Moortgat, G. K., Orkin, V. L., and Ravishankara, A. R.: Chemical Kinetics and photochemical data for use in atmospheric studies, Evaluation number 14, JPL Publications 02-25, Jet Propulsion Laboratory, Pasadena, CA, 2003.

Schwartz, S.: Mass-transport considerations pertinent to aqueousphase reactions of gases in liquid-water clouds, in Chemistry of Multiphase Atmospheric Systems, Springer, New York, 415471, 1986.

Seisel, S., Börensen, C., Vogt, R., and Zellner, R.: Kinetics and mechanism of the uptake of $\mathrm{N}_{2} \mathrm{O}_{5}$ on mineral dust at $298 \mathrm{~K}$, Atmos. Chem. Phys., 5, 3423-3432, 2005,

http://www.atmos-chem-phys.net/5/3423/2005/.

Shao, M., Lu, S., Liu, Y., Xie, X., Chang, C., Huang, S., and Chen, Z.: Volatile organic compounds measured in summer in Beijing and their role in ground-level ozone formation, J. Geophys. Res., 114, D00G06, doi:10.1029/2008JD010863, 2009.

Stier, P., Seinfeld, J. H., Kinne, S., and Boucher, O.: Aerosol absorption and radiative forcing, Atmos. Chem. Phys., 7, 52375261, 2007, http://www.atmos-chem-phys.net/7/5237/2007/.

Tang, Y., Carmichael, G. R., Kurata, G., Uno, I.,Weber, R. J., Song, C. H., Guttikunda, S. K., Woo, J. H., Streets, D. G., Wei, C., Clarke, A. D., Huebert, B., and Anderson, T. L.: Impacts of dust on regional tropospheric chemistry during the ACE-Asia experiment: A model study with observations, J. Geophys. Res., 109, D19S21, doi:10.1029/2003JD003806, 2004.

Tie, X., Madronich, S., Walters, S., Edwards, D. P., Ginoux, P., Mahowald, N., Zhang, R., Lou, C., and Brasseur, G.: Assessment of the global impact of aerosols on tropospheric oxidants, J. Geo- phys. Res., 110, D03204, doi:10.1029/2004JD005359, 2005.

Tang, M. J., Thieser, J., Schuster, G., and Crowley, J. N.: Uptake of $\mathrm{NO}_{3}$ and $\mathrm{N}_{2} \mathrm{O}_{5}$ to Saharan dust, ambient urban aerosol and soot: a relative rate study, Atmos. Chem. Phys., 10, 2965-2974, 2010, http://www.atmos-chem-phys.net/10/2965/2010/.

Usher, C. R., Al-Hosney, H., Carlos-Cuellar, S., and Grassian, V. H.: A laboratory study of the heterogeneous uptake and oxidation of sulfur dioxide on mineral dust particles, J. Geophys. Res. 107, 4713, doi:10.1029/2002JD002051, 2002.

Usher, C. R., Michel, A. E., and Grassian, V. H.: Reactions on mineral dust, Chemical Reviews, 103, 4883-4939, 2003.

Usher, C. R., Michel, A. E., Steca, D., and Grassian, V. H.: Laboratory studies of ozone uptake on processed mineral dust, Atmos. Environ., 37, 5337-5347, 2003.

Underwood, G. M., Song, C. H., Phadnis, M., Carmichael, G. R., and Grassian, V. H.: Heterogeneous reactions of $\mathrm{NO}_{2}$ and $\mathrm{HNO}_{3}$ on oxides and mineral dust: A combined laboratory and modeling study, J. Geophys. Res., 106, 18055-18066, 2001.

Ullerstam, M., Johnson, M. S., Vogt, R., and Ljungström, E.: DRIFTS and Knudsen cell study of the heterogeneous reactivity of $\mathrm{SO}_{2}$ and $\mathrm{NO}_{2}$ on mineral dust, Atmos. Chem. Phys., 3, 2043-2051, 2003, http://www.atmos-chem-phys.net/3/2043/2003/.

Ullerstam, M., Vogt, R., Langer, S., and Ljungstrom, E.: The kinetics and mechanism of $\mathrm{SO}_{2}$ oxidation by $\mathrm{O}_{3}$ on mineral dust, Phys. Chem. Chem. Phys., 4, 4694-4699, 2002.

von Kuhlmann, R., Lawrence, M. G., Crutzen, P. J., and Rasch, P. J.: A model for studies of tropospheric ozone and non-methane hydrocarbons: Model description and ozone results, J. Geophys. Res., 108, 4294, doi:10.1029/2002JD002893, 2003.

Wagner, C., Hanisch, F., Holmes, N., de Coninck, H., Schuster, G., and Crowley, J. N.: The interaction of $\mathrm{N}_{2} \mathrm{O}_{5}$ with mineral dust: aerosol flow tube and Knudsen reactor studies, Atmos. Chem. Phys., 8, 91-109, 2008,

http://www.atmos-chem-phys.net/8/91/2008/.

Wang, W., Ma, J. Z., Hatakeyama, S., Liu, X. Y., Chen, Y., Takami, A., Ren, L. H., and Geng, C.: Aircraft measurements of vertical ultrafine particles profiles over Northern China coastal areas during dust storms in 2006, Atmos. Environ., 42, 5715-5720, 2008.

Wang, Y. Q., Zhang, X. Y., Gong, S. L., Zhou, C. H., Hu, X. Q., Liu, H. L., Niu, T., and Yang, Y. Q.: Surface observation of sand and dust storm in East Asia and its application in CUACE/Dust, Atmos. Chem. Phys., 8, 545-553, 2008, http://www.atmos-chem-phys.net/8/545/2008/.

Zhang, Y. and Carmichael, G. R.: The role of mineral aerosol in tropospheric chemistry in East Asia - a model study, J. Appl Meteorol., 38, 353-366, 1999.

Zhang, Y., Sunwoo, Y., Kotamarthi, V., and Carmichael, G. R.: Photochemical oxidant processes in the presence of dust: an evaluation of the impact of dust on particulate nitrate and ozone formation, J. Appl. Meteorol., 33, 813-824, 1994.

Zhao, B.: Investigation of air pollution emission sources in North China, M. S. thesis, Chinese Academy of Meteorological Sciences, Beijing, 2007. 